\title{
Retail development in Turkey: An account after two decades of shopping malls in the urban scene
}

\author{
Feyzan Erkip ${ }^{\mathrm{a}, 1}$, Burcu H. Ozuduru ${ }^{\mathrm{b}, *}$ \\ ${ }^{a}$ Bilkent University, Faculty of Art, Design and Architecture, Department of Urban Design and Landscape Architecture, Ankara 06800, Turkey \\ ${ }^{\mathrm{b}}$ Gazi University, Faculty of Architecture, Department of City and Regional Planning, Celal Bayar Blv., Maltepe-Ankara 06570, Turkey
}

\begin{abstract}
The social, economic and environmental impacts of large-scale retail outlets on existing retail and urban systems have been extensively discussed in the planning literature. This article documents the last two decades of transformation in Turkey's retail sector, which have been characterized by a more organized development of the sector than traditionally existed. We begin our analysis with the late 1980s and early 1990s, when more-liberal and outward-looking policies began to emerge in Turkish economic policy. Changes in the economy and related legislation prepared a base for the subsequent transformations of that decade, culminating, especially in large cities, in the development of shopping malls as alternative retail spaces to traditional markets and stores on a shopping street. We believe that the Turkish case reveals specific aspects of resistance, adaptation and change, and thus needs a detailed account. After providing a general picture of retailing and its transformation in Turkey, we provide empirical evidence from Ankara, the capital city, through which all important dynamics of retailing are exemplified. To this end, we ask the following questions: What are the evolving processes behind the existing location patterns of shopping centres in Ankara? What is the extent of the change in definition of the new public realm? How do street retailers survive? Who are the actors and what are their approaches towards retail planning in Turkey? The answers to these questions may provide implications for urban policy and retail planning in Turkey. The case may also be interesting for countries experiencing similar patterns of change and development, that is, where the globalization process in retailing and consumption-related sites began later than in other countries and observed fastpaced development.
\end{abstract}

(C) 2014 Elsevier Ltd. All rights reserved.

Keywords: Retail development; Shopping centers; Resilience; Urban policy

\section{Contents}

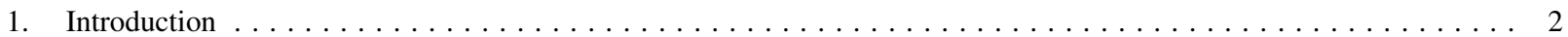

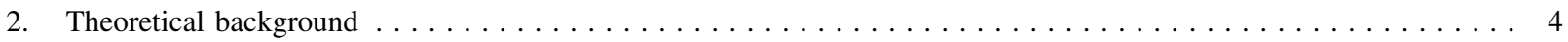

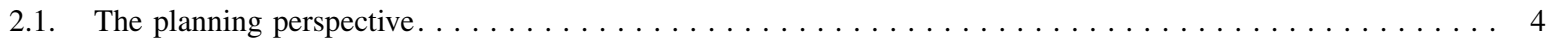

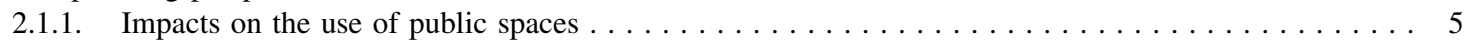

\footnotetext{
* Corresponding author. Tel.: +90 312582 3701; fax: +90 3122320586.

E-mail addresses: feyzan@ bilkent.edu.tr (F. Erkip), bozuduru@gazi.edu.tr (B.H. Ozuduru).

${ }^{1}$ Tel.: +90 3122901592.
} 


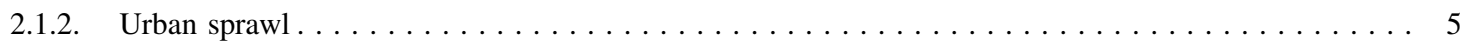

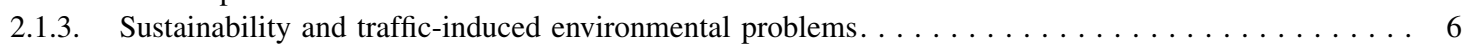

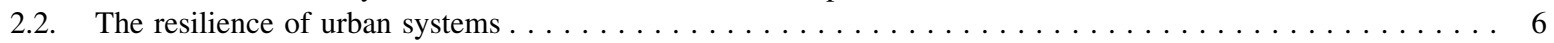

3. Retail development in Turkey: defining periods $\ldots \ldots \ldots \ldots \ldots \ldots \ldots \ldots$

3.1. The first period: global impacts on the organization of the retail sector, $1990-2000 \ldots \ldots \ldots$

3.2. The second period: the influx of shopping centres, $2000-2010 \ldots \ldots \ldots \ldots$

3.3. The third period: a laissez-faire approach by the central government, and market dominance in 2010 and beyond 15

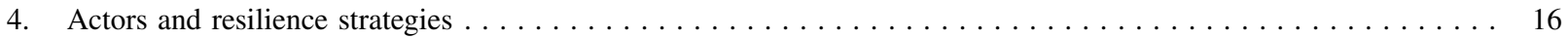

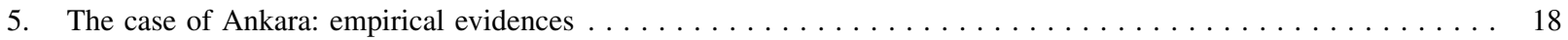

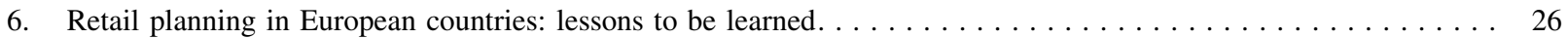

7. Concluding remarks: implications for the future of retail planning in Turkey $\ldots \ldots \ldots \ldots$

7.1. Regulation of the relationship between large-scale and traditional retailers $\ldots \ldots \ldots \ldots$

7.2. Provision of definitions and standards . . . . . . . . . . . . . . . . . . . . . . . 29

7.3. Rule set-up for site-selection feasibility analyses and relationships to development plans . . . . . . . . . 29

7.4. Arrangement of the roles of public and private actors in the development process . . . . . . . . . . . 29

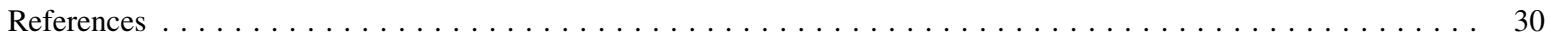

\section{Introduction}

The social, economic and environmental impacts of large-scale retail outlets on existing retail and urban systems have been extensively discussed in the planning literature (Guy, 1998; Knox, 2008; Ozuduru, Varol, \& Ercoskun, 2014; Southworth, 2005; Teller, 2008). Despite the relatively late influence of global economic trends in Turkey (beginning in the late 1990s), foreign investment penetrated the country's retail sector quite quickly. This development attracted the attention of scholars regarding various aspects of Turkish retailing, and the subject has generated a growing literature (see, for example, Erkip, Kizilgun, \& Mugan Akinci, 2013; Erkip, Kizilgun, \& Mugan Akinci, 2014; Erkip, 2003, 2005; Ozuduru \& Varol, 2011; Ozuduru et al., 2014; Tokatli \& Boyaci, 1998). This article documents the last two decades of transformation in Turkey's retail sector, which have been characterized by a more organized development of the sector than traditionally existed. Although many aspects of this transformation have been explored, here we present a more thorough analysis of the specific periods of retail development, each of which experienced a different kind of change. In this study, we explore this topic using various theoretical perspectives on urban retailing.

We begin our analysis with the late 1980s and early 1990s, when more liberal and more outward-looking policies began to emerge in Turkish economic policy. Changes in the economy and related legislation prepared a base for the subsequent transformations of that decade, culminating, especially in large cities, in the development of shopping malls as alternative retail spaces to traditional markets and stores on a shopping street. Global cultural influences and mass media also made consumption in shopping malls more desirable for Turkish citizens. Further, improved economic conditions and credit options provided Turkish people with the opportunity to purchase globally branded products. Similar to the situation in many other countries, these modern and organized retailers threatened the livelihood of small-scale, traditional shop owners. However, some small retailers viewed the changes as an opportunity to modernize and develop strategies to make themselves more resilient. We believe that the Turkish case reveals specific aspects of resistance, adaptation and change, and thus needs a detailed account. The resilience concept in relation to urban systems has evolved in many ways, and in this paper, we discuss the strategies of both small- and large-scale retailers (i.e. traditional retailers and shopping mall developers) during the past decades in relation to urban development. The resilience level of a city's retailing sector can be increased by new urban policies, and their major objectives should be specifically set out so as to integrate traditional retailers into the urban scene and increase city centres' vitality and viability. Traditional retailers are the pillars of urban life in city centres; with the current influx of new shopping centres, older retailers can become more resilient by adopting new marketing strategies in the ever-changing, dynamic retail market. These malls should be able to re-invent themselves and remain in the markets.

The period of shopping mall development that began in the late 1980s in Turkey continues today, with increasing competition between new shopping malls causing the decay of first-generation malls, as expected. An unexpected outcome of this trend, however, is the 
insistence of central and local planning bodies and authorities to allocate every piece of vacant land in the urban core, including green areas or public land designated for other uses, to shopping mall development. We believe that the last two decades of shopping mall development reflect different economic and social dynamics, thus we analyze them separately in this paper.

The first period of retail development in Turkey occurred mainly between 1990 and 2000, during which shopping malls emerged as part of the scene and daily life of large cities. In the second period, between 2000 and 2010, they flourished in quantity and quality, and citizens created a huge demand for them. The reasons behind this demand were not completely economic; the modernity provided by these retail spaces was a major appeal (see Erkip, 2003 for a detailed account of this issue). In the same period, shopping mall investments extended to smaller cities. The share of international capital in Turkey also increased, indicating a growing interest from foreign investors and developers in shopping mall development. These two periods also witnessed the resilience strategies of actors in the sector. In the first period, actors and citizens adapted to sector changes, and in the second period they developed resilience strategies to survive and/or thrive under the new competitive conditions. Changes to the retail sector in the first two periods occurred with little comprehensive planning. Now, a third period seems to have begun, and it requires a more holistic strategy. We explore the indicators of this claim in the following sections.

From 1990 to 2010 three groups of shopping centres emerged in Turkey. Those in the first group are called integrated shopping centres, which are small in size (between 2500 and $5000 \mathrm{~m}^{2}$ ) and located close to city centres. Shopping malls in the second group tend to be located in the suburbs and/or are individually structured centres designed separately from their surroundings. The third group is composed of various land uses, such as offices, entertainment venues, residences and retail stores. Most new shopping malls today comprise the third group: large-scale 'urban transformation projects' with customers ready to shop there. For this reason, these structures can sustain themselves more easily than first-generation shopping centres. Since national and local developers in Turkey are mostly from the construction sector, this situation provides an opportunity to develop construction projects that involve various uses. New subdivisions are being built in various urban areas, both in the core and on the periphery.
The competition between new consumption spaces and traditional ones has important impacts on urban public spaces. The emergence of shopping centres has changed the concept of the public realm, and thus the design principles of public spaces; these centres offer a climate-controlled enclosed space where people can more comfortably do the things they used to do in outdoor public spaces, i.e., window shop, eat and drink, meet people, etc. Considering the segregation between women and men, children and adults, rich and poor, and religious and secular in Turkey's public spaces, these new mall spaces seem to offer more-inclusive areas. Citizens' tolerance for each other, especially for those overlooked by modern and educated groups, seems to increase in these public, but privately owned environments, which then create a new kind of public space (Erkip, 2003). Women find a more secure place to browse; children are allowed, and even encouraged by their parents, to spend time in these controlled spaces and religious and secular people share the mall space more tolerantly because they see it as a territory of consumption only. There is surveillance in all such spaces, and in the Turkish case, this aspect reveals an interesting distinction: many people do not mind being observed because they believe such surveillance is not intended for them, but for others (Mugan \& Erkip, 2009). These prevailing characteristics of shopping malls necessitate further discussion on the definition and features of public spaces in Turkey, a topic that we discuss in general in this paper, saving a detailed exploration for a future study.

Urban density and the ratio of young people in Turkey are quite high compared to other European countries. These facts create a dynamic use of urban spaces and the potential for the simultaneous use of globally designed consumption spaces (such as shopping malls) and traditional street retailers in urban centres, as well as for using open spaces (such as parks) for leisure activities and socializing (Erkip et al., 2014).

Turkish urban planning has been controlled by the central government since the beginning of the 2000s, and this includes retail planning. Attempts at special legislation, first in 2004 and then in 2006, to restrict the impact of shopping centres on street retailers was blocked by the power behind the large capital invested in shopping centres, on the grounds that it would limit their operations and decrease their profit margins. However, such laws should take into account other planning regulations. For example, to maintain a lively central business district (CBD), which research has shown is vital to a healthy urban core, municipal governments should provide larger pedestrian areas, 
revise car-oriented policies, increase parking and public transportation in city centres, and offer clean, comfortable and secure green areas with amenities (Ercoskun \& Ozuduru, 2011). Such policies would increase the attraction level of CBDs and contribute to the resilience of traditional retailers. Without these aids, independent retailers are left vulnerable, insecure and usually unorganized; they often develop individual resilience strategies to survive in a competitive retail environment. Retailer strategies in the absence of comprehensive planning, however, are usually reactive instead of proactive, and while successful against slow-burn changes, they are generally not capable of resisting shocks. A holistic and central retail policy involving all actors, including citizens, is necessary to maintain a lively retail environment, characteristic of traditional Turkish retailing. Turkish planners could benefit from the experiences of other countries, which are in a later stage of shopping mall development. Such efforts would make Turkish cities more sustainable and livable as well as making the sector more resilient to global and/or domestic crises and changes. This paper addresses issues raised by other countries' retail development experiences to assist the Turkish case.

Another significant factor for Turkey is its ongoing and lengthy process of European Union (EU) membership, which makes it different from other countries that experienced shopping mall development in the same period. Although relations between the EU and Turkey are unreliable at this time, the potential of membership in the first two periods forced many sectors, including the retail sector, to modernize and better organize to satisfy EU requirements (EIU, 2009). Some countries who enjoy more-comprehensive retail planning are EU members, and their experiences demonstrate the role the public sector can play in retail planning and offer a framework that can help integrate retail planning into urban policy. (For detailed analyses of selected countries' retail planning schemes, see Cities, 2014, special issue).

Our premise can be framed with the following questions in relation to the above-mentioned periods: How did the retail sector transform in Turkey? What were the motives for change in different periods? How did actors react and respond to the changes in the sector? How did these changes influence urban land use patterns? What were the roles of planning bodies and legislation in shaping the sector and urban development?

After providing a general picture of retailing and its transformation in Turkey, we provide empirical evidence from Ankara, the capital city, through which all important dynamics of retailing are exemplified. To this end, we ask the following questions: What are the evolving processes behind the existing location patterns of shopping centres in Ankara? What is the extent of the change in definition of the new public realm? How do street retailers survive? Who are the actors and what are their approaches towards retail planning in Turkey? The answers to these questions may provide implications for urban policy and retail planning in Turkey. The case may also be interesting for countries experiencing similar patterns of change and development, that is, where the globalization process in retailing and consumption-related sites began later than in other countries and observed speedy development.

\section{Theoretical background}

To evaluate the impacts of shopping malls on traditional retail forms and urban land use in Turkey, we adopt a broad perspective, composed of components of different theories on urban development. The following sections outline these theoretical perspectives, each of which focuses on different aspects of urban development in relation to transformations in the retail sector.

\subsection{The planning perspective}

Development of a shopping centre requires a comprehensive analysis of its impact on the built environment and urban living. Selecting an inappropriate site can create traffic congestion, environmental degradation and urban sprawl, as well as disposition of employment, independent retailers and other resources. The retail sector is one of a city's major economic activities, which (1) creates employment, (2) is a major source of income through the taxes it generates and (3) reflects the community's viability and vitality (Mazza \& Rydin, 1997). Therefore, retail sales can be regarded as a function of several policies in urban planning, such as urban containment, the price of agricultural land and the percentage of government and municipality revenue from property taxes and general sales taxes. This multifaceted perspective means that shopping centres should be a major topic in urban policy-making because of their effects on so many aspects of city life.

As an example of economic impacts, shopping centres change the quality of employment in the retail sector. In many countries, traditional stores cannot survive due to competition from malls; some move into a shopping centre, while others close their businesses and become an employee of a store in a mall selling similar products and services. Some retailers close their 
stores and find unrelated (or no) employment. Much retail employment is thus driven to the urban fringe, where the number of shopping centres is higher. The standardization of work through big-box training programmes diminishes the importance of employees' personal abilities, and the nature of relationships with customers is less personal compared to traditional stores. Neumark, Zhang, and Ciccarella (2006) find that the opening of a Wal-Mart store decreases retail wages by $7.5 \%$, with each Wal-Mart worker displacing 1.51.75 other retail workers in the region. Similarly, Bernstein Research (2005) finds that big-box stores displace up to six local businesses, increase retail employment but substantially decrease wage levels and destroy historical commercial areas.

In the following sections, we analyze the impacts of shopping centre development within an urban policy perspective. The impacts of shopping centres on (1) public spaces, (2) urban sprawl, (3) sustainability and (4) traffic-induced environmental problems are among the major issues we consider. (For a detailed discussion of this perspective with a focus on the US can be found in Ozuduru and Guldmann (2013).

\subsubsection{Impacts on the use of public spaces}

The problem of social exclusion appeared when private spaces for shopping were developed and people began to spend more time in these spaces and less time in traditional shopping streets. Shopping centres have become the new public spaces of suburban areas and of urban cores (Banerjee, 2001; Erkip, 2003; Garreau, 1992; Ghosh \& McLafferty, 1987). However, they are owned by private entities and are not, in fact, public spaces. Erkip (2005) shows that these spaces do exclude some people in Turkey, not only on the basis of income but also on the basis of social class. Other scholars emphasize the importance of accessible retail facilities by all segments of society and note that an increasing number of shopping centres discriminate against the mobility impaired, the elderly and low-income households because the malls are only accessible by car (Barata-Salgueira \& Erkip, 2014; Guy, 1998, 2007). Guy (2007) also points out that such exclusion can be controlled by enhancing local shopping and public transportation policies and recommends preserving local shopping in traditional urban districts, improving poor-quality retail facilities and supporting surviving businesses through urban policies.

Staeheli and Mitchell (2006) show that mall owners do not consider their shopping spaces as gathering places or new kinds of downtowns, and do not allow for the gamut of user rights that a truly public setting offers.
They suggest that shopping centres are purposefully built to limit access and are designed to attract a certain market niche, providing a feeling of safety and comfort to the targeted consumers. They also suggest that youth access is restricted because of the associated challenging and disruptive behaviour. This aspect is verified by Mugan and Erkip (2009) in the Turkish context.

Southworth's (2005) findings, based on field surveys and in-depth interviews, imply that the new forms of suburban public spaces share similar attributes with main streets. The author defines various elements of the suburban public space, including main streets, strip malls, atrium malls, townscape malls, main street malls, malled main streets and hybrids, and analyzes their implications for urban design in terms of pedestrian connectedness; comfort; visible and accessible transit alternatives; places for social activity serving people of various ages, ethnicities and social groups; mixed-use characteristics; street scale for comfortable pedestrian crossings; controlled or uncontrolled automobile access; parking; scale; design and transparency to engage people with the place. Shamsuddin and Ujang (2008) attempt to identify place attachment and the influence of place identity on traditional shopping streets, and they specify the attributes influencing place attachment as accessibility, vitality, diversity/choice and transaction, among others, and conclude that traditional streets enhance place attachment and meaning in contrast to other retail spaces. Standardization in the design of shopping malls leads to a controlled experience, whereas public spaces can provide various levels of publicness through different spatial and physical features. Nemeth (2009) suggests the importance of privately owned public spaces in the future of urban spaces and proposes that management should provide physical features that will help increase the level of accessibility and use in such spaces.

\subsubsection{Urban sprawl}

Developers all over the world have built more out-ofcore shopping centres in recent years than in the last two decades, predicting that suburbs would welcome this new retail space (Knox, 2008; Lang, 2003). In contrast, residents, environmentalists and planners have argued that an excessive amount of such retail development has been accompanied by impervious parking areas that increase (1) storm water runoff, washing nitrogen, heavy metals and sediments into urban streams; (2) local urban heat-island effects and (3) shopping travel, with associated increased pollution and greenhouse gas emissions (NOACA, 2000), and that the number of such developments should be reduced. The reliance of 
consumers on cars encourages developers to build larger parking lots, creating stand-alone shopping centres surrounded by a desert of parking (Beyard \& O’Mara, 2005). Barata-Salgueira and Erkip (2014) also note that sprawl causes many environmental and social problems, with its impact, such as increased car use and lack of pedestrian access to retail spaces. In addition, malls' box-like architecture increases their negative impacts because they are built to be economically efficient and functional, not environmentally friendly.

Although urban sprawl follows different trajectories in different countries, there is evidence that compact cities decrease the ecological footprint of urban areas and reduce energy consumption and pollution because they encourage walking, have improved public transport access (Bromley, Tallon, \& Thomas, 2005), are developed in smaller land parcels and buildings and are accompanied by smaller parking facilities. Similarly, "new urbanism" design offers alternative uses for parking areas, such as "lining a parking deck with tiny retail spaces occupied by offbeat and artsy businesses" (cnu.org, 2007), and encourages traditional mixed-use city centres, with smaller retail stores, more landscaping elements and fewer parking spaces.

\subsubsection{Sustainability and traffic-induced environmental problems}

The environmental impacts of suburban shopping centres include issues related to the low curb appeal of retail buildings and the above-noted environmental problems caused by parking areas and increased vehicle travel. Notably, the environmental impact of a retail centre extends beyond local jurisdictions (NOACA, 2000). Retailing is one of the most traffic-generating land uses, and retail centres built on the outskirts of towns and cities on major traffic arterials and transit interchanges to achieve high visibility and accessibility contribute to this problem. Additionally, heavy traffic and the turning manoeuvers necessary to access a mall generate a higher number of accidents. Once a suburban retail centre is built on a main transportation route, traffic load increases and the transportation network evolves considerably (Evans-Cowley, 2005).

The literature extensively discusses the issue of shopping travel due to the increased use of cars and the subsequent increase of carbon dioxide emissions. Using cars instead of public transport for shopping travel increases energy consumption and pollution emissions (Mazza and Rydin, 1997). Banister (1997) points out that there was a $36 \%$ increase in car ownership across Europe between 1980 and 1990 and that transport accounts for over a quarter of carbon dioxide emissions in the UK. Therefore, an effective retail planning policy should be designed to minimize the use of private vehicles and to promote developments at readily accessible locations with alternative means of public transportation, or to develop clustered retail units to encourage multi-purpose trips (Guy, 2007). Ibrahim (2002) explains that Singapore has adopted an integrated retail and transport development policy, which regulates the use of private cars and encourages the use of public transport.

The importance of shopping locally to reduce trafficrelated pollution is well documented. Banister (1997), investigating density, settlement size and location of employment facilities, implies that local shopping areas should be promoted. He points out that a higher-density location can reduce trip lengths as well as the proportion of trips made by car, and that it is also easier to provide public transport services to such locations.

\subsection{The resilience of urban systems}

Resilience is a concept borrowed from ecological research and developed by researchers in the social sciences, mainly geography and economics (see Muller, 2011 and Lang, 2011 for detailed discussions on this topic). Simmie \& Martin (2010, p. 28), claiming that there is no universally accepted definition of resilience, propose an "adaptive model" to understand how geographical regions adjust to disturbances through time (see also Replacis, 2011 for a detailed discussion of the evolution of the concept of resilience). "In this context, the resilience of an urban retail system is defined as the ability of different types of retailing to adapt to changes, crises or shocks that challenge the system's equilibrium without failing to perform their functions in a sustainable way" (Replacis, 2011). In a sense, resilience is the new form of sustainability, and is thus a current topic of discussion (see, for example Stumpp, 2013; Davoudi, 2012 and Barata-Salgueira and Erkip, 2014 on its meaning and applicability to social sciences and planning). Shaw (2012) calls it a paradigm shift with new challenges, as the focus seems to be on individuals rather than institutions. However, depoliticizing the concept of resilience without asking questions about the reasons for disturbances or the nature of resilient systems should be approached cautiously (Porter \& Davoudi, 2012).

According to Stumpp (2013, p. 2) "resilience as a concept is more dynamic, it is non-linear and crosslinked, complex so to say, and it embraces uncertainty." These qualities make it incompatible with current planning methods and invite new and more creative 
approaches. There are two main components that define the resilience concept: one is inherent to the system in question, whereas the other involves factors affecting the system. The latter is easy to recognize because it reveals itself in the form of large shocks or crises (such as natural disasters, wars or bankruptcies), as slow-burn changes from the incremental impacts of global economic factors or as small-scale crises that require quick adaptation. The first component is defined by a system's capacity for resilience and determines how it reacts to such impacts without disturbing its functionality in a new balance. This capacity can be defined by flexibility, adaptability, preparedness or communication between agents, among other components. As Collier et al. (2013, p. 1) suggest, "some of [the] social barriers include the capacity of a community to adapt and to influence adaptive processes, local planning bodies, the degree of community capital and the relative size of an area within the larger entity." This component is harder to analyze due to its dynamic and complex character, which is specific to the context. How much these factors explain the changes in Turkish retailing is one of the main questions explored in this paper.

Simmie and Martin (2010) note Foster's (2007) distinctions between actors' spontaneous and prepared responses in the adaptation process. Erkip et al. (2014, p. 113) define spontaneous resilience as "the typical reactive strategy that individual retailers undertake; it is essentially focused on outlets' retail activity. Planned resilience, however, requires the involvement of associations, municipalities and other public actors and is more comprehensive." We believe that in most cases, spontaneous resilience better explains the Turkish situation.

Muller (2011, p. 5) points out the inherent features that make some cities more resilient than others, including "human perception, behaviour and interaction, as well as decision-making, governance, and the ability to anticipate and plan for the future." "Cities with an efficient network of centres that deliver goods and services to the vicinity should be more sustainable than the ones without such a network" (BarataSalgueira \& Erkip, 2014, p. 108). However, from a spatial point of view, linkages between retailing and urban development in different countries have not always followed similar trajectories. Spatial resilience is closely linked with the identity of the urban system (Cummings, 2011). Stumpp (2013, p. 2) indicates that "in the context of resilience [adaptation] now refers to sudden disturbances, to recovery and renewal and it tries to prepare for the un-projectable, the impossibleto-imagine." There are indications that Turkish cities have well adapted to the changes that have occurred in two decades of mall development, because street retailers and other agents survived these transformations, using various innovative resilience strategies (Erkip et al., 2014; Ozuduru et al., 2014). Thus, we believe that the system has exhibited a high level of flexibility and adaptation. Despite the sector's lack of preparation, creative resilience strategies emerged, but the absence of a cohesive plan may well become a serious problem in the case of a shock.

\section{Retail development in Turkey: defining periods}

Before starting our analysis, we provide a brief historical context of Turkish retailing beginning from the Ottoman period.

During Ottoman times, Istanbul was the main consumer market and the trade link between the Ottoman Empire and the world economy. The market, which was completely controlled by the state, realized its transactions in bazaars - the most famous one, the Grand Bazaar, is still an attraction point for tourists and Istanbul citizens. Other types of bazaars included carsis (markets), bedestens (covered bazaars) and hans (hostels for traders). Ethnic groups traditionally involved in commerce "became the most dynamic intermediaries between European capital and local markets" after a treaty opened the empire to foreign capital in 1838 (Tokatli \& Boyaci, 1999). Westernization during the nineteenth century resulted in Istanbul becoming a dual city joined by the Galata Bridge (Toprak, 1995). Toprak (1995) relates the development of consumption patterns with the change in retail forms in the Ottoman period, pointing out the influence of the West. Louvre, Au Lion, Bon Marche, Au Camelia, Bazar Allemand, Carlmann et Blumberg, Orosdi Back, $\mathrm{Au}$ Paon and Baker are large stores of European origin, which opened franchises in Istanbul in the second half of the nineteenth century. This period is seen as a consequence of liberal economic policies and in fact, Geyikdagi and Geyikdagi (2009) claim that this is the "first globalization" in Turkish history. They further point out the resemblance between the first and second globalization: both were fuelled by consumption without sufficiently attracting foreign direct investment (FDI) and resulted in a large trade deficit.

During the Republican period, small-scale convenience stores, butchers, grocers and independent stores for other consumer goods, as well as bazaars and street vendors, were the dominant retail format until the 1970s. Franz, Appel, and Hassler (2013), analyzing the 
changes in grocery retail and the spatial diffusion of supermarkets and hypermarkets in Turkey in four phases, document the country-specific motives of a more modern retail format. Interestingly, in 1953, the Turkish government, in cooperation with Istanbul's municipality, invited the Swiss Migros to invest in a joint venture in Istanbul, particularly to benefit from their know-how in food retailing. This arrangement was a different mode of foreign investment because it was initiated by the state rather than by the pull factors for FDIs (Franz et al., 2013). Starting with 20 mobile sales trucks, Migros opened its first self-service store in 1957. Despite financial and organizational problems that the company experienced in its first few years, it "started to vertically integrate parts of the supply chain" and "became involved in food processing" (Ozcan 2008, cited by Franz et al., 2013).

Following Migros' example, Turkish supermarket chains Gima (1956), OYAK (1963) and Tansas (1973) were established and began becoming part of the urban Turkey: all of these stores were public investments through local institutions. Although Turkey shares similarities with some Central and Eastern European countries in the development of food retailing, the Migros case is unique (Franz et al., 2013). The abovenoted countries also experienced a much faster spatial diffusion of supermarkets, hypermarkets and discounters after 1990 than Turkey did (Franz et al., 2013).

Before the 1980s, Turkey's retailing and manufacturing sectors were characterized by import-substituting industrialization and a publicly or privately owned - but government-dependent - industrial sector that showed little responsiveness to changes in international circumstances (Tokatli \& Boyaci, 1998). The business environment was protected and directed to the domestic market, and FDIs were discouraged. In 1960, Turkey experienced an economic boom, followed by an economic crisis in the late 1970s that showed the need for economic restructuring. In the 1960s, accumulation of agrarian and commercial capital was converted to industrial capital; importers became industrialists and the people investing in import-substituting industries were the same people who had imported and distributed those goods in the previous era; thus there was a fuzzy boundary between manufacturers and traders (Tokatli \& Boyaci-Eldener, 2002). Traditionally, retailers were small and independent and they selected locations by intuitive judgement, experience, familiarity and coincidence. They had limited business skills and limited capital, and cash-run retail businesses appeared to be a convenient investment area (Ozcan, 2000). However, small businesses had few opportunities to compete in local markets, accumulate capital or co-operate with each other (Ozcan, 2000).

Beginning in 1980 , by recognizing and coming to terms with global competition conditions, Turkey adopted a more outward-oriented development strategy to cultivate its export potential. From 1981 to 1993, a particularly high rate of economic growth occurred (Tokatli \& Boyaci, 1998). The late 1980s' shift from manufacturing to consumption (Tokatli \& Boyaci, 2001; Tokatli \& Erkip, 1998), as well as decreasing government control, increasing privatization and increasing flexibility in regulating foreign investments, began to change the organizational structure of the retail sector. In addition, "the financial sector, and especially medium to small-scale banks, are attracted to cash-rich retail business in a high-inflation, high-interest rate macro-economic environment" (Ozcan, 2000; p. 107), especially between 1990 and 2000 .

The main characteristics of the periods in which we analyze Turkey's retail sector and its development can be seen in Table 1. We focus on the two decades between 1990 and 2010 as the point marking the integration of Turkish retailing into global capital and changing the sector's local and traditional character. This change is observed mainly by shopping mall development in Turkey's urban scene, beginning in metropolises and expanding to the whole country in fewer than 20 years.

\subsection{The first period: global impacts on the organization of the retail sector, 1990-2000}

Despite the above-mentioned changes in the Turkish economic structure, globalization of the retail sector started quite slowly - over a ten-year period. It took another decade for domestic and international retailers to become extensively involved in retailing, mainly because of the country's fragmented retail structure, which makes performing in a large-scale retail environment difficult (Tokatli \& Boyaci, 1998). Beginning in the 1990s, domestic and transnational corporations (TNCs), the latter usually joint ventures with domestic partners, began to change the nature of the sector, with large and organized retail investments creating a rich consumer market (see Tokatli and Boyaci for a list and the retail activities of these corporations).

The first period of large-scale organized retail in Turkey began with a few shopping centres that opened in the late 1980s and became city landmarks. At the beginning of the 1990s, investments were dominantly in large-scale food retailers as the anchors of new shopping centres. Initially, such spaces were developed 
Table 1

Defining periods of retail transformation in Turkey.

\begin{tabular}{|c|c|c|c|}
\hline Before 1990 & 1990-2000 (first period) & $\begin{array}{l}2000-2010 \text { (second } \\
\text { period) }\end{array}$ & $2010+($ third period $)$ \\
\hline Traditional retail forms & $\begin{array}{l}\text { First generation of shopping } \\
\text { mall developments }\end{array}$ & $\begin{array}{l}\text { Influx of shopping } \\
\text { centre development }\end{array}$ & $\begin{array}{l}\text { Accumulated impact of } \\
\text { global economic crises }\end{array}$ \\
\hline $\begin{array}{l}\text { Small-scale and local } \\
\text { investments }\end{array}$ & $\begin{array}{l}\text { Penetration of large capital } \\
\text { and foreign investment and } \\
\text { partnership }\end{array}$ & $\begin{array}{l}\text { Partnership of foreign } \\
\text { capital with national } \\
\text { capital }\end{array}$ & $\begin{array}{l}\text { Increasing political } \\
\text { tension in the region/ } \\
\text { country }\end{array}$ \\
\hline $\begin{array}{l}\text { Aspirations for global } \\
\text { integration (1980s) }\end{array}$ & $\begin{array}{l}\text { Legislation in line with } \\
\text { economic development }\end{array}$ & $\begin{array}{l}\text { Increasing investments } \\
\text { of national and local } \\
\text { capital }\end{array}$ & $\begin{array}{l}\text { Decaying shopping mall } \\
\text { investments }\end{array}$ \\
\hline $\begin{array}{l}\text { Transition from import-substitution } \\
\text { to export-oriented and } \\
\text { outward-looking economy } \\
(1980 \text { s) }\end{array}$ & - Tax Law (1992) & $\begin{array}{l}\text { Increasing boom in } \\
\text { construction sector }\end{array}$ & Hesitant foreign capital \\
\hline \multirow{4}{*}{$\begin{array}{l}\text { Promise of EU membership } \\
\text { (1980s) }\end{array}$} & - Law of Capital Market (1994) & Further legislation & New shopping alternatives \\
\hline & $\begin{array}{l}\text { - Turkish Competition Authority } \\
\text { (1997) }\end{array}$ & $\begin{array}{l}\text { - Ownership Rights } \\
\text { for Foreigners (2003) }\end{array}$ & $\begin{array}{l}\text { Cities prone to natural } \\
\text { disasters }\end{array}$ \\
\hline & $\begin{array}{l}\text { - Establishment of real estate } \\
\text { investment trusts (REITs) (1998) }\end{array}$ & $\begin{array}{l}\text { - Attempts to control } \\
\text { retail development by } \\
\text { law (2004 and 2006) }\end{array}$ & Contested urban space \\
\hline & Optimism about EU membership & $\begin{array}{l}\text { Economic crisis (2008) } \\
\text { Optimism about EU } \\
\text { membership }\end{array}$ & Lessening EU influence \\
\hline
\end{tabular}

by a number of European companies in partnership with major Turkish companies. Turkey became an investment focus for the following reasons: (1) a population greater than that of most European countries, (2) a significant share of a younger population, who could be easily diverted towards consumption and (3) the quick rate of returns on investment compared to many European countries at the time. Groupe Carrefour of France collaborated with Sabanci Holding in 1996 and opened CarrefourSa hypermarkets, ChampionSa supermarkets, and DiaSa discount markets. Germany's Metro Group opened MetroGrossmarket, Real Hypermarket, and Praktiker home improvement and do-it-yourself stores. Towards the end of the 1990s, a new wave of shopping centres opened, again initiated by international investments, including Dutch (Corio and ECE) and German (MultiMall) investment companies (Ozuduru \& Varol, 2011).

Because of these developments, Turkish society could now access a large number of goods and services in one structure, and 'going to the mall' became an increasingly popular urban activity. The Turkish market was inclined to consumption, and thus both demand and supply expectations were met.

Rapid urbanization, increase in per capita income and level of education, increasing use of telecommunication tools, young demographics, increased mobility by car or public transportation, more contact with foreign cultures, new aspirations and lifestyle changes paved the way to modern retailing, particularly in Istanbul and Ankara, Turkey's largest cities. Domestic and foreign brands sold in shopping malls and on high streets became attractive to an urbanized, better-off and younger population with a desire to be a part of global consumption trends. After a few decades of modernization efforts, the demand for modern consumption spaces seemed an appropriate response. Middle-income groups were not excluded from this new consumption experience; for various reasons, they constitute the crowd in most shopping malls. "The growing economy, favourable consumer demographics, and a relatively fragmented retail landscape make Turkey attractive to international retailers. Disposable income has increased at a compound annual growth rate (CAGR) of 3.6 percent since 2005, while the percentage of households earning less than $\$ 15,000$ dropped from 53 percent to 45 percent. The middle class's expanding purchasing power is spurring sales growth, while wealthy locals and international tourists are increasing luxury goods sales" (Kearney, 2013). It is important to note that the increase in income accompanied by cultural changes provided a well-established basis for the development of new retail formats, including shopping malls. 
For the reasons stated above, the Turkish retail market still has a larger potential for investment than many other European countries, given the high ratio of retail expenditures to consumption expenditures (AMPD, 2010; Deloitte \& Planet Retail, 2010). Table 2 shows the appeal of the Turkish market to foreign investors.

Table 3 shows that the share of FDI inflows in wholesale and retail trade, among other sectors, peaked in 2008. Overall, after 2005, that share decreased significantly. The decrease after 2010 shows that the retail market has begun to be dominated by domestic capital, which also supports the argument that foreign investment in retailing has shifted to other countries (Ozuduru \& Varol, 2011).

As in other countries, large-scale retailers have had a significant impact on traditional and independent retailers in Turkey, who are more vulnerable because they cannot predict economic change as fast as organized retailers can (who, in fact, often create that change). Large-scale international retailers have bargaining power with manufacturers and can offer the same quality of goods and services more cheaply than local retailers. In most cases, the middleman is eliminated from the process (Tokatli \& Boyaci-Eldener, 2002). When the retail transformation in Turkey began, small retailers did not have sufficient funds or knowledge to develop proven coping strategies. Some organized retailers attempted to help (granted, with their own interests in mind) by providing small-scale retailers with an organization model similar to franchising. In return, they asked for a share of the profits. For example, Swiss-based retailer Migros partnered with a Turkish company (Koc Holding) to change the business models of independent retailers by offering service strategies and know-how. Those retailers have become small-scale outlets where customers can find the same convenience goods and services offered in hyper/supermarkets. These stores resemble traditional convenience stores, called bakkal in Turkish, and even have a similar name (Bakkalim, meaning 'my bakkal'), but are more modern, hygienic and organized. The strengths of these independent retailers are their proximity to customers and customers' familiarity with them. People can buy their daily goods from these retailers and their weekly goods from the hyper/ supermarkets.

The central government, on the other hand, developed new tools to support large-scale investors because they could easily collect taxes from them; traditional independent retailers are infamous for their tax evasion. Legislation such as the Tax Law (1992), the Law of Capital Markets (1994) and the establishment of REITs (1998) support large capital, which provides economic advantages to its shareholders. The Turkish Competition Authority was established in 1997 to regulate the sector by exerting control over competition in it. Smallscale retailers were not effectively protected by these

Table 2

Economic indicators and retail expenditures for Turkey and some European countries (2008) (million dollar).

\begin{tabular}{|c|c|c|c|c|c|}
\hline Countries & $\begin{array}{l}\text { Population } \\
\text { (million) }\end{array}$ & $\begin{array}{l}\text { Disposable } \\
\text { income }\end{array}$ & $\begin{array}{l}\text { Consumption } \\
\text { expenditures }\end{array}$ & $\begin{array}{l}\text { Retail } \\
\text { expenditures/ } \\
\text { consumption } \\
\text { expenditures }(\%)\end{array}$ & $\begin{array}{l}\text { Retail } \\
\text { expenditures }\end{array}$ \\
\hline England & 61.2 & 1828.2 & 1673.8 & 38.5 & 644.6 \\
\hline France & 61.9 & 1730.3 & 1435.4 & 39.5 & 567.0 \\
\hline Spain & 45.3 & 884.2 & 850.0 & 42.4 & 360.4 \\
\hline Italy & 59.0 & 1491.7 & 1.264 .4 & 31.3 & 395.8 \\
\hline Germany & 82.2 & 2210.8 & 1780.2 & 38.1 & 678.3 \\
\hline Holland & 16.4 & 394.3 & 357.9 & 41.6 & 148.9 \\
\hline Poland & 38.0 & 280.2 & 259.7 & 49.9 & 129.6 \\
\hline Russia & 141.1 & 673.9 & 684.2 & 47.1 & 322.3 \\
\hline Sweden & 9.2 & 221.9 & 207.3 & 37.2 & 77.1 \\
\hline Portugal & 10.7 & 168.5 & 150.7 & 33.0 & 49.7 \\
\hline Czech Republic & 10.3 & 88.2 & 86.1 & 55.8 & 48.1 \\
\hline Ireland & 4.4 & 134.7 & 13.3 & 53.7 & 60.9 \\
\hline Belgium & 10.6 & 268.3 & 229.2 & 41.2 & 94.4 \\
\hline Hungary & 10.0 & 85.9 & 89.6 & 49.5 & 44.4 \\
\hline Romania & 21.5 & 122.3 & 124.6 & 32.8 & 40.9 \\
\hline Slovakia & 5.4 & 48.1 & 44.8 & 37.7 & 16.9 \\
\hline Greece & 11.2 & 213.9 & 238.8 & 33.3 & 79.5 \\
\hline Turkey & 71.5 & 581.3 & 484.4 & 48.0 & 232.5 \\
\hline
\end{tabular}

Source: GYODER (2008, p. 51). 
Table 3

Foreign direct investment (FDI) inflows to Turkey by economic sectors.

\begin{tabular}{|c|c|c|c|c|c|c|c|c|}
\hline Economic sectors & 2005 & 2006 & 2007 & 2008 & 2009 & 2010 & 2011 & 2012 \\
\hline Agriculture, forestry and fishing & 0.1 & 0.0 & 0.0 & 0.3 & 0.8 & 1.3 & 0.2 & 0.4 \\
\hline Industry & 9.7 & 11.9 & 26.7 & 35.0 & 60.9 & 46.2 & 49.6 & 54.6 \\
\hline Mining & 0.5 & 0.7 & 1.8 & 1.0 & 3.3 & 2.2 & 0.9 & 2.1 \\
\hline Manufacturing & 9.2 & 10.6 & 22.0 & 26.7 & 24.5 & 14.8 & 22.3 & 43.4 \\
\hline Electricity gas, water & 0.0 & 0.6 & 3.0 & 7.2 & 33.2 & 29.2 & 26.4 & 9.1 \\
\hline Services & 90.2 & 88.1 & 73.2 & 64.8 & 38.3 & 52.5 & 50.2 & 45.0 \\
\hline Finance & 47.1 & 39.4 & 60.9 & 41.2 & 10.4 & 26.0 & 36.6 & 14.2 \\
\hline Construction & 0.9 & 1.3 & 1.5 & 2.2 & 3.7 & 5.0 & 1.9 & 14.3 \\
\hline Wholesale and retail trade & $\underline{0.8}$ & $\underline{6.6}$ & $\underline{0.9}$ & $\underline{14.1}$ & $\underline{6.1}$ & $\underline{7.0}$ & $\underline{4.4}$ & $\underline{2.2}$ \\
\hline Other services & $4 \overline{1.4}$ & $4 \overline{40.8}$ & $\overline{9.9}$ & 7.2 & $1 \overline{8.1}$ & $1 \overline{4.5}$ & $\overline{7.3}$ & $1 \overline{4.3}$ \\
\hline Total & 100.0 & 100.0 & 100.0 & 100.0 & 100.0 & 100.0 & 100.0 & 100.0 \\
\hline
\end{tabular}

Source: YASED (2013).

Bold values indicate the major economic sectors (i.e. The industry sector is composed of mining, manufacturing and electricity, gas, water subsectors; services sector is composed of finance, construction, wholesale and retail trade and other services subsectors. Agriculture, forestry and fishing sector does not have any subsectors). Italic and underlined values point out the significance of the fluctuations in the share of FDI flows in that particular subsector (i.e. After 2005, the share of wholesale and retail trade decreased significantly; and it peaked in 2008, and the domestic capital shifted to other countries after 2010).

changes, however, because the central government focused on large foreign capital.

Towards the end of the first period, large Turkish retail companies started to invest in other countries in the region, such as Russia, Azerbaijan and Kazakhstan (Ozcan, 2000). They filled the role of Western TNCs, which did not find these countries sufficiently attractive to invest in. One such case is Albania, a country gearing up for modern retail formats (Kursunluoglu Yarimoglu, 2014). "More than Turkey's 50 largest companies operate currently in Albania" (Kursunluoglu Yarimoglu, 2014, pp. 121-122). Turkish textile products are predominantly exported to Albania.

\subsection{The second period: the influx of shopping centres, 2000-2010}

The second period observed a high growth rate of shopping centres in Turkey. Gross leasable area - the primary indicator of shopping centre size - and the number of shopping malls increased steadily (see Figs. 1 and 2). Shares of foreign investments in shopping malls also increased, with more penetration of large, dominantly European, capital (see Fig. 3). This decade was the most favourable period for shopping centre development in Turkey. Regardless of the global economic crises that significantly affected international investments globally, between 2008 and 2010, the number of shopping centres increased significantly, revealing that the shopping centre investors had their own equity capital through investment in other sectors.
As of 2013, the number of shopping centres in Turkey was 368 , with a total gross leasable area of $10,679,370 \mathrm{~m}^{2}$. In 2006 , the number of employees in Turkey's organized retail sector was 300,000 , growing to 585,000 in 2011 , an increase of approximately $95 \%$. As observed from Figs. 1 and 2, the number of centres increased most rapidly after 2004, two years after the Justice and Development Party (Adalet ve Kalkınma Partisi or AKP), whose development policy supports consumption and investment in shopping centres, came to power. Franz et al. (2013, p. 57) note that "under the new leadership, liberalization was taken forward and investors became more confident due to the growing political stability in the country. These political developments, together with the growing purchasing power of consumers in Turkey, had impacts on the retail sector: TNCs intensified their investments."

After 2003, the share of local investors also increased significantly; shopping centre investment and management has become a lucrative business for many. The provision of ownership rights for foreigners in 2003 accelerated global investment in profitable sectors in Turkey, especially in shopping malls and office complexes. Although the interest of international investors is persistent (Fig. 3 shows that the number of international investors conducting business in Turkey was increasing until 2010), the share of national and local investors in shopping centre development has also increased, and now exceeds international investors. Observing the quick and high rates of return, national companies in sectors such as tourism, manufacturing, marine trade and construction also began investing in 


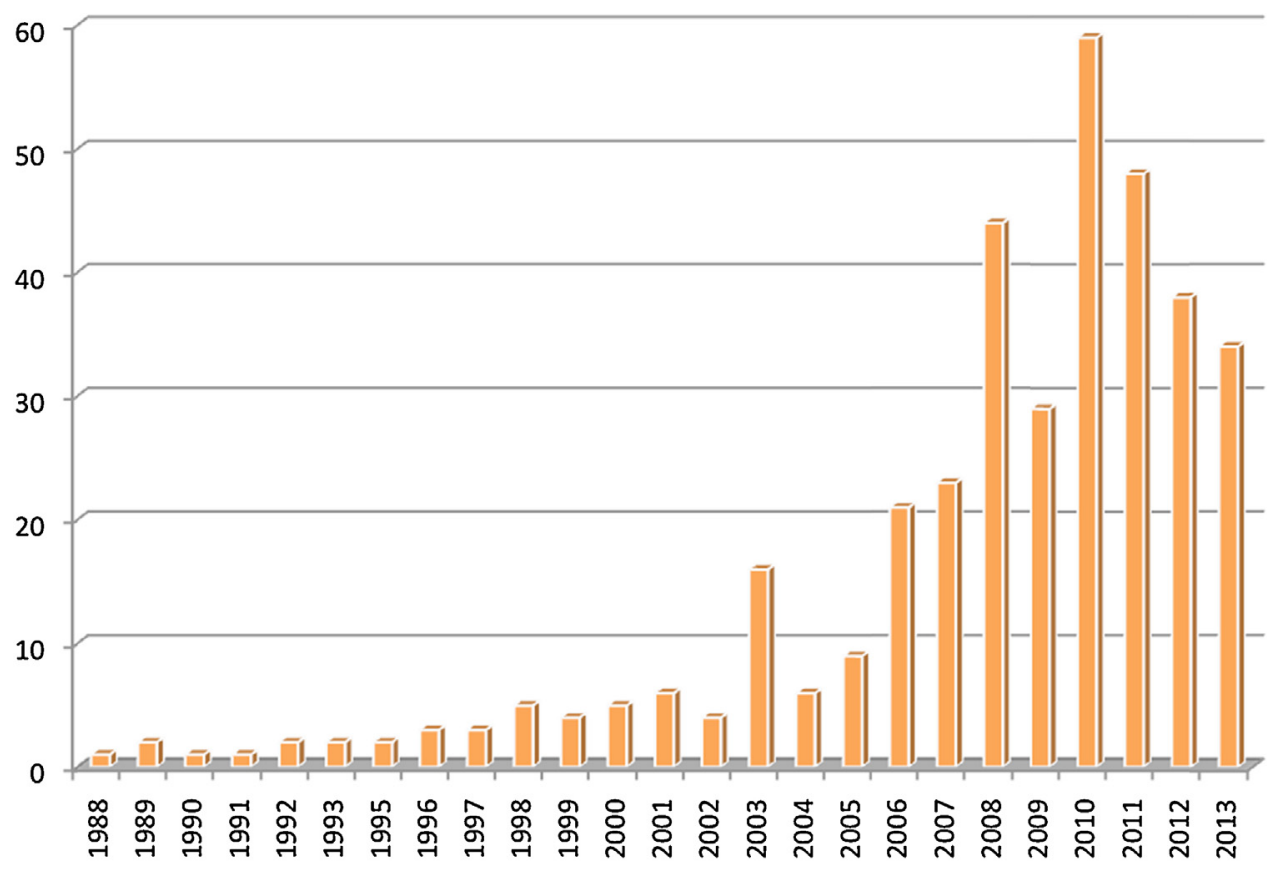

Fig. 1. Number of shopping centres in Turkey by year. Source: Authors' search.

the retail sector. This increase in the share of local investors makes the sector more resilient to crises in the global economy. Further, that the equity capital of national retail investors is financially supported by other sectors causes retail investors to continue to pursue shopping centre construction projects.

In 2008, on the eve of the economic crisis, the second influx of shopping centre openings in Turkey occurred

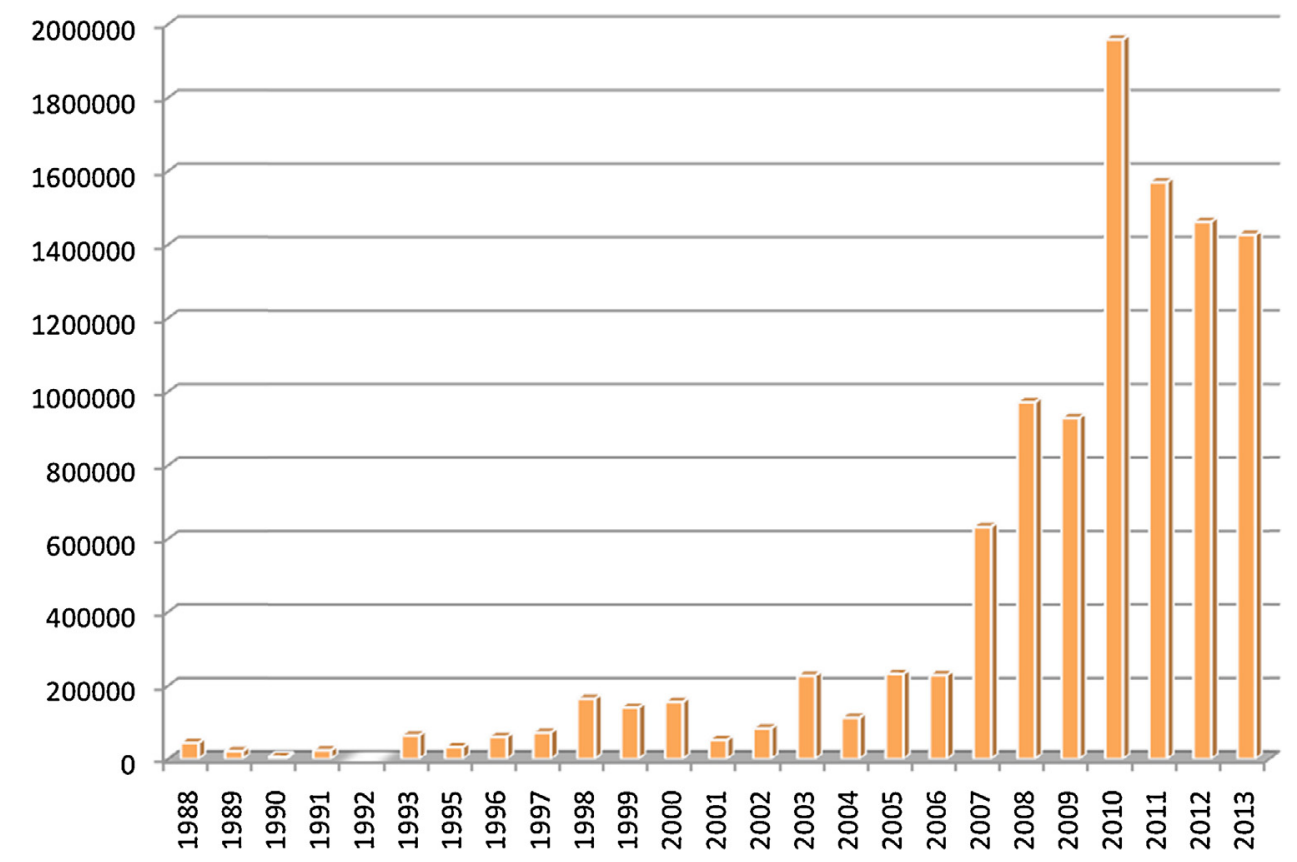

Fig. 2. Total gross leasable area $\left(\mathrm{m}^{2}\right)$ of shopping centres in Turkey by year Source: Authors' search. 


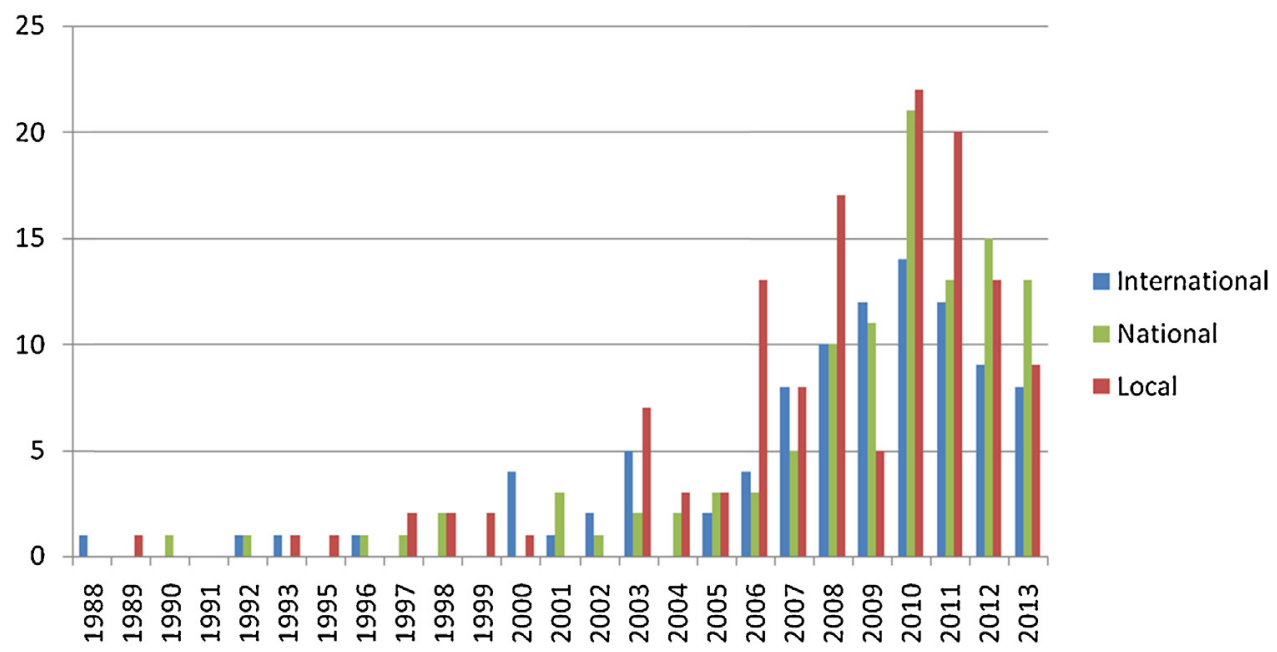

Fig. 3. Number of shopping centres by investor type.

Source: Authors' search.

(Ozuduru \& Varol, 2011). Although the number of shopping centres in Istanbul greatly exceeds those in all other Turkish cities, it should be noted that there is also a high rate of growth in shopping centre investments in many other cities compared to their population, making these spaces an important component of urban life all over Turkey (Fig. 4).

In the second period, the power of retail companies over government institutions also increased. These companies have become significant businesses and have been able to negotiate development rights with government agencies. In many cases, local and central government institutions offered flexibility in land development once the construction of a shopping centre had been agreed upon. Investors and developers started shaping retail legislation and planning strategies. Government agencies, chambers of commerce and other related retail organizations discussed later in this article have declared that they prefer the retail sector to be organized by these large-scale retailers because they provide consistent sources of tax revenue, provide better employment opportunities, increase the sector's productivity level, offer cheaper, reliable high-quality goods and services to consumers, have increased the pace and amount of FDI and opened up the economy to global markets (Ozuduru \& Varol, 2011).

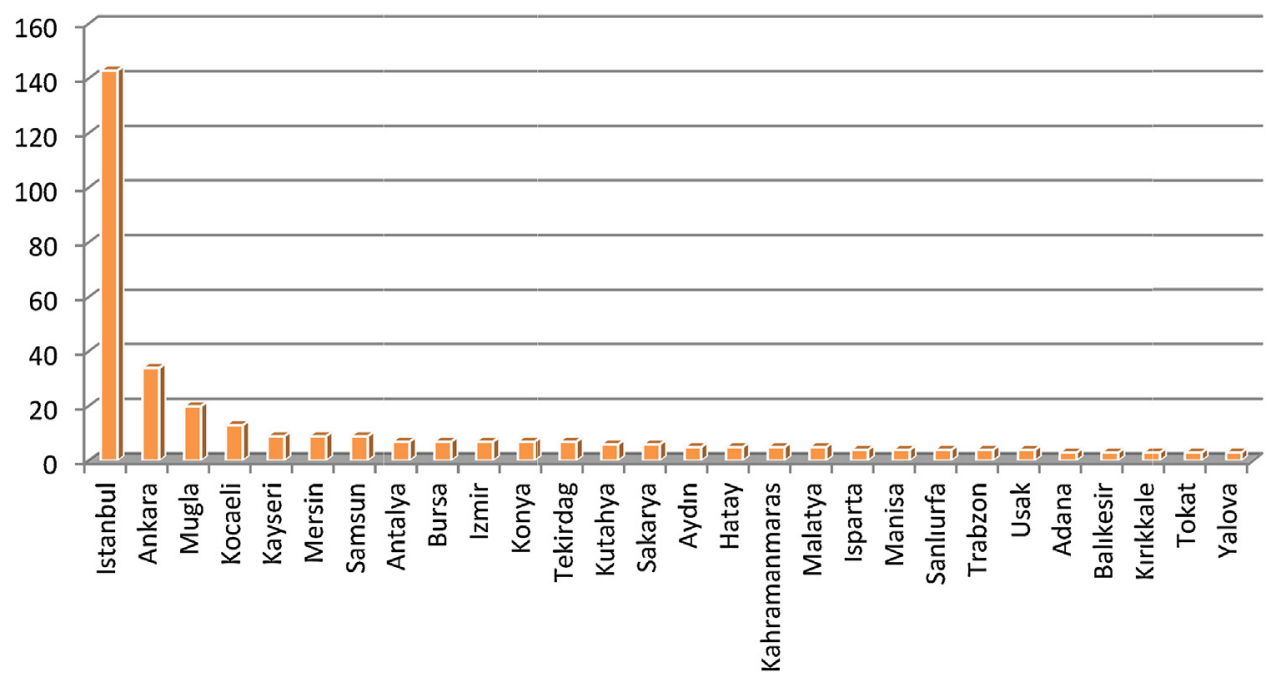

Fig. 4. Number of shopping centers in Turkish cities.

Source: Authors' search. 
The resilience process also dominated the second period. Traditional retailers, who were caught unaware by the changes in the first period, developed new skills and strategies to adapt to market changes. They increased their level of service to generate loyalty among customers, such as ensuring high-quality products, reasonable prices or 24-h service. They clustered to offer comparison shopping for certain goods and services. For example, jewellers clustered in one location in a city and retailers selling technological products clustered in another location. We analyze the resilience strategies of the traditional and the more organized segments of the sector in the following sections.

In 2004, Turkey's Ministry of Industry and Commerce initiated a major regulatory effort: "The aim of the proposed law is three-fold: (a) consideration of consumer rights, (b) the provision of modern urbanization in cities and (c) balancing competition between various segments of the retail sector" (Erkip et al., 2013, p. 336). However, this law has not yet been passed, apparently because it requires locating stores and shopping malls with sale areas larger than $5000 \mathrm{~m}^{2}$ to beyond the city centre. In fact, the law cites traffic congestion, insufficient parking facilities, unfair competition between large suppliers and exclusion of smallscale retailers from the retail market as consequences of shopping mall development. Although different retail segments appear to support the law, the power structure is still in favour of large capital, and this established support by central and local governments discourages the progress of the legislative process. This situation also prevents realizing aspects of the law that would ensure more holistic retail planning, such as demand analysis, traffic planning, infrastructure development, environmental analysis and sustainability measures. The law has been re-drafted several times but has not passed due to its monitoring components, which will hurt large-scale retail businesses (The Ministry of Customs and Trade) (www.gtb.gov.tr).

Critics of the proposed law cite an outdated framework that suggests no solutions to mitigate the impact of large-scale retailers on traditional retailers, provides no definitions or standards for size or location choice, and neither sets up rules for site-selection feasibility analyses or relationships to development plans nor sets out the roles of public and private organizations in the development process. Retail legislation should contribute to the broader framework of resilience, which can be arranged by developing strategies to address the above criticisms. Collaborative action between local governments and other interested parties should be the primary aspects of this process.
The other important project of this period is documented in the 2009 report of Turkey's Council of Urbanization of the Ministry of Public Works and Settlement (now the Ministry of Environment and Urbanization) (www.eukn.org). This project, called the Integrative Urban Development Strategy and Action Plan for Sustainable Urban Development (KENTGES) aimed to increase the level of livability in urban areas and took a holistic approach to all aspects of urban development in Turkey, in accordance with the last (ninth) national development plan, effective between 2007 and 2013. The KENTGES initiative was proposed as a guide for urbanization, settlement and planning with the collaboration of public institutions, local governments, private investments, NGOs and citizens. In other words, it attempted to cover all parties affected by the urban development process.

In the first phase of the project, an Urban Development Consortium was organized; more than 150 institutions with more than 500 experts contributed to the strategy document. In the second phase, an action plan was developed, covering proposals for transportation, infrastructure, housing, disaster preparedness, protection of natural and cultural heritage, climate change, energy efficiency, renewable resources, ecology, migration and social policies, economic structure and participation. Although retail planning was not listed as a separate topic, with its links to the abovementioned issues it was discussed as part of urban sustainability. Urban transportation is one of the most important issues related to retail development. Despite (or perhaps because of) decentralization tendencies, housing and workplaces in urban cores cause serious traffic problems in many Turkish cities.

Urban transformation began in the 1980s in Turkey to improve the conditions of low-quality settlements, but its aim changed in the 1990s. Central areas of cities with historical and cultural sites and workplaces were bought up for development, such as shopping malls and entertainment sites. The KENTGES report criticized such urban transformation and called for government to focus on social, cultural and historical development and sustainability.

Another important component of KENTGES was the 'sustainable urban form,' which defined alternative forms of urban development in line with the EU perspective. According to this approach, excessive decentralization and sprawl are not as sustainable as compact, corridor or multi-centred development. The report made heavy use of international documents and the EU's approaches to urbanization. Themes, targets, strategies and actions were defined accordingly and 
'urban macroform' and 'urban centre' were selected as KENTGES' main premises. Strategies on developing shopping sites were considered directly related to the future of urban centres, and the need for legislation on the scale, location and structure of new shopping developments was stressed. The impact of such developments on existing shops and workplaces was also noted.

The then-Ministry of Public Works and Settlement was to spearhead the project, with local governments, universities and chambers of commerce as participating constituents. The period between 2010 and 2012 was devoted to the short-term arrangements (such as limiting working days and hours, establishing tools for price control and promotions) for drafting the legislation on shopping centre developments, but now the project has been 'postponed.'

\subsection{The third period: a laissez-faire approach by the central government, and market dominance in 2010 and beyond}

Turkey's retail market is one of the most prosperous and dynamic in the Europe area (Cushman \& Wakefield, 2012), although the total number of shopping centres is still lower than in many European countries. The average gross leasable area per 1000 people is about $220 \mathrm{~m}^{2}$ in Europe and $100 \mathrm{~m}^{2}$ in Turkey. This potential for growth makes Turkey the country with the highest pipeline of shopping centre areas after Russia (Cushman \& Wakefield, 2013, May). Between the end of 2010 and the third quarter of 2013 in Turkey, the total number of malls increased by $47.6 \%$. Turkey's two largest cities (Istanbul and Ankara) hold 50.5\%, or just over half, of the country's shopping centres. The total gross leasable area of shopping centres in Turkey today is $10,700,730 \mathrm{~m}^{2}$, with almost half $(44.5 \%)$ of this property in Istanbul. Kocaeli has the fourth-highest number of malls in the country because of its proximity to Istanbul. Mugla, with its proximity to towns that attract many tourists, ranks third in shopping centre investments (see Fig. 4).

High streets are also attractive locations for retail stores, especially for luxury brands such as Chanel, which rents space in Istanbul on Bagdat Street, and Armani, which has a space on Nisantasi Street, both upscale shopping areas. "However, it is generally very difficult to find space in existing streets and shopping centres. New leases and relocations happen very quickly, which is something of an obstacle for international retailers" (Cushman \& Wakefield, 2013/ 2014). Luxury brands also desire spaces in new shopping centres: Louis Vuitton, Christian Dior, Fendi and Bulgari are tenants of Istanbul's newly opened Zorlu Centre. According to Kearney (2013), Turkey is growing as "a fashion capital with a slew of talented local designers." In addition to favourable consumer demographics, the country "is also in an ideal position as a production and logistics hub, with a 3.6 percent share in global textile and ready-wear exports."

This third period also observed a nationwide construction boom, with the retail sector the primary economic motive. At four percent, Turkey has one of the highest rent-growth rates in shopping centres in the Euro-area (Germany also stands at four percent and Poland's rate is seven percent) (Cushman \& Wakefield, 2012). However, "the completion rate slowed during the second half of 2012; indeed, only 123,000 $\mathrm{m}^{2}$ GLA (gross leasable area) was brought to the market, through the opening of two new schemes in Istanbul, compared with the $250,000 \mathrm{~m}^{2}$ completed in the first half of $2012^{\prime \prime}$ (Cushman \& Wakefield, 2013, May). Uncoordinated site-selection of shopping malls has created competition between old and new malls, and some older ones have closed. Although Istanbul has the most shopping centres in the country it also has the highest mall-closure rate. About $10 \%$ of the shopping centres opened in the last two decades are now closed, and some fear that this negative trend might increase. Vacant spaces in shopping malls from tenants who have not renewed their leases constitute another planning problem. It is not surprising that the tenant selection process has started to become more open-minded, as the owners of some specialty clothing firms attest. For example, Tesettur Giyim, a clothing choice for religious women, claims that shopping malls became more willing to sell their products after economic crises (Zaman Pazar, 2009).

Online shopping is another important dynamic affecting Turkey's retail sector. Although still a small part of total retail sales, this mode of shopping has averaged a $32.8 \%$ annual growth rate in Turkey over the last five years (Cushman \& Wakefield, 2013, July). Apparently, there is important potential in e-commerce. A.T. Kearney (2012) calls the Turkish case a "quiet success" and believes that there is a "strong logistical infrastructure" for online purchases, noting that "the Turkish government has also aided the e-commerce boom by enacting digital laws that protect online consumers and oversee e-commerce companies." The current capacity of the market is $\$ 1.3$ billion, which is appealing for foreign retailers. "In 2011, Naspers, the South African media conglomerate, acquired 70 percent of Markafoni, one of Turkey's largest private online 
shopping sites" (A.T. Kearney, 2012). It is also predicted that potential online shoppers' fears of transactions over the internet will be alleviated by companies such as hepsiburada.com that provide secure payment methods.

Macroeconomic data indicate that there are signs of a downward slope in the economy (Gurkaynak \& SayekBoke, 2013) and that the current positive indicators might not be long-lasting. The AKP's construction craze can be traced in the country's urban development and has been criticized by anti-government groups. The 2013 protests sparked by the Gezi Park incident, where the government wants to replace green space in Istanbul with a mall, indicate that this understanding of urban development is not well accepted by all citizens. The demonstrations against Gezi Park's destruction expanded into protests about citizens' other frustrations with the government, such as economic inequalities. A similar demonstration took place recently in a smaller city of Turkey, Amasya, where a park was to be replaced by a petrol station, and another protest occurred in Istanbul, against its proposed third airport, which is to be built by destroying a forest (BBCNews, 2014). There is also evidence that the Gezi Park unrest caused a decline in consumption expenditures, particularly in the few months following the protests (EIU, 2013). Even though the situation now seems to be stable, further conflicts may occur, and this reflection of citizens' opinions should be acknowledged rather than stifled.

\section{Actors and resilience strategies}

Lack of effective representation of nonprofit retailing and citizen organizations in the urban planning process may be another source of conflict in future developments. In earlier studies, we discussed the roles of governmental and nongovernmental organizations (NGOs) in shaping the retail sector, in addition to the roles of large and small retailers (Erkip et al., 2013; Varol \& Ozuduru, 2010). Ministries and local governments dominate the process of legislation and its implications for the sector under the influence of largescale retailers, but professional organizations such as the Confederation of Turkish Tradesmen and Craftsmen (TESK) and other local NGOs (formed by street retailers and inhabitants) do play a limited role in this planning environment.

International companies have a structured organization and their investments rely on various analyses, feasibility studies and scientific knowledge. National and local companies, on the other hand, usually only belong to an informal network and follow the lead of international investors. Turkey's local and national retail sector developers became more sophisticated in the second period because of the increasing competition between shopping centres. Initially, only developers were involved in mall construction at the national and local levels. As the need to improve the institutional and organizational structure emerged, other sectors became involved. For example, in the 1990s, it was not until after a shopping centre was built that its management searched for tenants. By the late 2000s, specialized leasing firms, such as Jones Lang LaSalle, AVM MFI Partners and MultiTurkMall, were searching for tenants and developing a marketing strategy for shopping centres before their construction. Sometimes these leasing firms also help determine new themes and branding. Today, investors, developers and leasing firms dominate the sector, which, despite government involvement and legislative attempts, is essentially unregulated and uncontrolled. Further, the retail market is increasingly influenced by national and local investors. For the above reasons, international investors and developers have become hesitant about doing business in Turkey. Although some companies may consider this environment an opportunity, others find it too risky, especially when the economic situation becomes less favourable (for a detailed account of the developer's perspective on the Turkish retail structure, see Erkip et al., 2013). However, recent figures indicate that Turkey is still a growing and attractive market that is moving up in the Global Retail Development Index (GRDI), "nearing its peak growth state" (Kearney, 2013). There are also signs of factors pushing some companies, such as German Praktiker (facing operational and competitive challenges, according to Kearney (2013) and British Tesco (who has established an agglomerate with Turkish Kipa) to exit the Turkish market (Planet Retail, 2013)). Transnationals have the flexibility, hence the resilience, to leave the market when it is no longer profitable. It is too early to determine what kind of decision will be made, but largescale investors should be closely observed in terms of resilience strategies.

Several non-profit retail organizations and associations were established in Turkey in the early 2000s, with the aim of improving the sector by providing opportunities for advancement, education and a network for exchanging knowledge, ideas and projects. Two major such organizations are the Association of Shopping Centers and Retailers and the Association of Shopping Center Investors. These groups aim to contribute to the advancement of organized retailers and increase their share in the retail sector, increase 
productivity levels and education, lobby for protective legislation, compute and declare the relevant sector indices and indicators and disseminate scientific research in the sector to teach retailers how to decrease their vulnerability to changes in the economy. Other leading organizations include the Association of Retail Brands and the Association of Real Estate Investment Trusts. The above groups demonstrate how organized retailers can cooperate and develop a platform to exchange ideas and knowledge. For example, it is through these organizations and associations that shopping centre development merged with other land uses (residential, entertainment, office, etc.); the groups identified that such developments are more profitable and last longer than stand-alone shopping centres.

The resilience process dominated the second period, when global impacts began to be observed in the economy and retail sector actors needed to adapt to those changes. The main actors in the Turkish retail sector are traditional small-scale and independent retailers, as well as organized large retailers usually associated with international capital. The groups' resilience strategies are different: the former adopts a reactive strategy because it cannot predict changes as quickly as the latter. Further, the former has neither sufficient financial resources to develop better strategies nor much influence over government agencies dealing with retailing. Through various projects and programmes, Confederation of Turkish Tradesmen and Craftsmen purports to help provide solutions to the problems of small-scale retailers, yet its efforts remain ineffective due to some of the representatives' political aspirations (Ercoskun \& Ozuduru, 2011).

Street retailers have not been able to generate such strong alliances. Although they have developed some informal social networks, the expertise within and the clout of these groups is not comparable to those of organized retailers. Many independent retailers were eager to become part of organized chains to attain more power. The main impact of the above-noted EU requirements was on street vendors, open markets and bazaars, where the food products did not meet hygiene standards. Some positive changes in the conditions of such retailers were realized through the municipalities, such as in the case of simit (a round Turkish bread) vendors, who were provided with semiclosed mobile units to replace their open tables (see Fig. 5). Now, large capital has become involved with simit, offering it in many franchised cafes in Turkey, some European cities and even in the United States (Fig. 6). Simit is becoming part of the Turkish image in the global market.

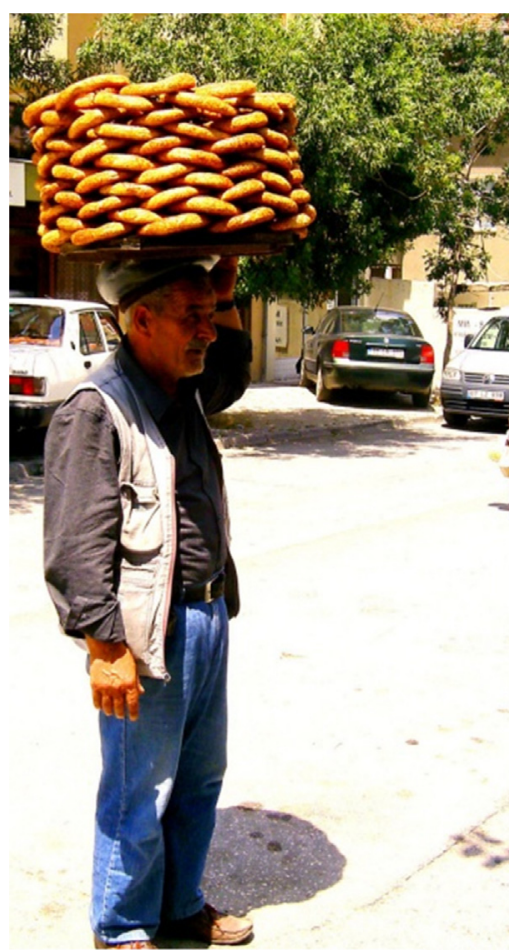

Fig. 5. A simit vendor.

Source: http://applsgr32.deviantart.com/art/Simitci-amca-171132180 (accessed 15.01.14).

Resilience strategies are applied according to the capacity and power of actors in a sector, and while organized retailers have many advantages over smallscale, traditional ones, they make little use of informal methods of connection, which always involve a personal component. For example, small businesses

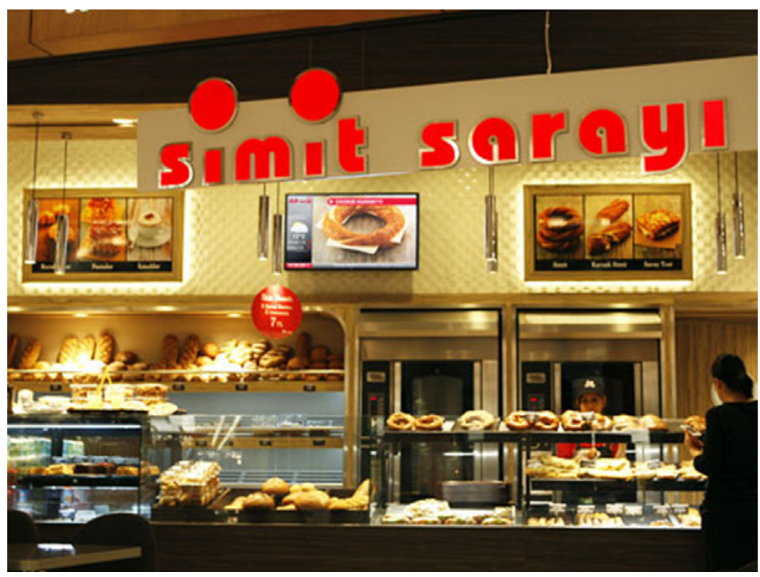

Fig. 6. A Franchised Simit Sarayi Café.

Source: http://www.sektorankara.com/firm_detail.php?id=108 (accessed 15.01.14). 
usually take phone orders, cultivate neighbourly relations and uphold traditional values and habits. In Turkey, they have also increased the quality and variety of their products, partly assisted by the emerging professional networks.

Shopping centres compete among themselves especially when they are located in the urban core. In addition to their general advantages, such as climate control and parking facilities, malls create niches through customer segmentation, attract higher-quality (mainly global) products and use their leverage in negotiating with local and central governments, mostly regarding mall location; zoning and planning regulations are often changed to provide a site for a new shopping centre. In the following section on Ankara, we analyze this aspect in detail.

Although street retailing is expected to be negatively influenced by shopping mall development, Turkish retailers seem to be coping with the current situation through innovative strategies. Location helps - many street retailers are sited in pedestrian areas - yet they do have concerns and complaints about shopping mall development and local governments' attitude towards the retail situation. These factors are also exemplified in the Ankara case.

\section{The case of Ankara: empirical evidences}

With the establishment of the Turkish Republic in 1923, Ankara became the capital. As a reflection of the modernization period, development plans were prepared for the city to control its growth and expansion. Until the decentralization policies of the 1970s and the corridor developments of the 1990s, Ankara was a compact city. Over the last few decades, it has grown to the west and southwest, with large subdivisions and residential areas that have attracted middle- and higherincome households. Wealthy households are increasingly choosing to relocate from inner-city neighbourhoods to the southwest. This housing pattern has affected Ankara's transportation network as well as people's trip-mode choice. Although it is a common view that shopping centres increase private car use, in Ankara, they equally increase the use of public transportation modes. Many government institutions, which are Ankara's largest employers, are also relocating to the southwest, and the city has become increasingly car-dependent (Ankara Greater Municipality, 2007; Babalik-Suttcliffe, 2013); the number of cars per 1000 people has been increasing and as of 2009 was at 191, the highest in Turkey (TUIK, 2009).
Ankara's social, economic and demographic characteristics are also unique in Turkey. The numbers of students and public officials are higher than in other cities, and middle-income citizens dominate the population. Squatter settlements in the northern and eastern parts of the city have been transformed into high-rise apartments, mainly for middle-income households.

We selected Ankara as a case study for several reasons. First, as the capital city, it has the secondlargest population in Turkey, with more than four million people. Second, Ankara ranked second in a national study (DPT, 2003) regarding the share of wage earners, levels of literacy, university graduates and gross domestic product, which are significant indicators of urban development. These features are among the reasons investors have frequently chosen Ankara for their developments (Ozuduru \& Varol, 2009).

Third, Ankara has the country's highest share of younger people (between 20 and 30) (Ankara Development Agency, 2011), mainly because it houses 18 of the 179 universities in Turkey. Thus, $8.5 \%$ of all university students in Turkey are enrolled in universities in Ankara (YOK, 2014). Fourth, the variety of recreational activities is relatively low in Ankara, compared to Istanbul and Izmir, which border the Aegean Sea and have a warmer climate.

The pace of change in Ankara's retail supply increased in the 1990s, parallel to the retail changes nationally. The city's first shopping centre, Atakule, was established in 1989, followed by Karum, Begendik, Galleria and the Ankuva/Bilkent Center. By 2005, there were nine malls in Ankara, and this number increased three times in five years, to reach 30 in 2010. Between 2007 and 2010 alone, 14 new shopping centres opened and the total gross leasable area more than doubled (Ozuduru \& Varol, 2011). Currently, there are 37 shopping centres and a total gross leasable area of 1,279,780 $\mathrm{m}^{2}$ (see Figs. 7 and 8). The total gross leasable area of shopping centres per capita in Ankara was the highest in Turkey in $2011\left(190 \mathrm{~m}^{2} / 1000\right.$ people), which led to the construction of even more malls in the city.

Despite its growing sprawl, Ankara is a fairly accessible city by public transportation; its vehicleoriented urban policy means the municipality constructs new roads instead of investing in public transportation. Shopping centres are also often located in the newly developing and most car-accessible areas of the city, usually on major highways. For this reason, the malls attract customers from almost all of the greater urban area. The city's south and southwest areas have a high 


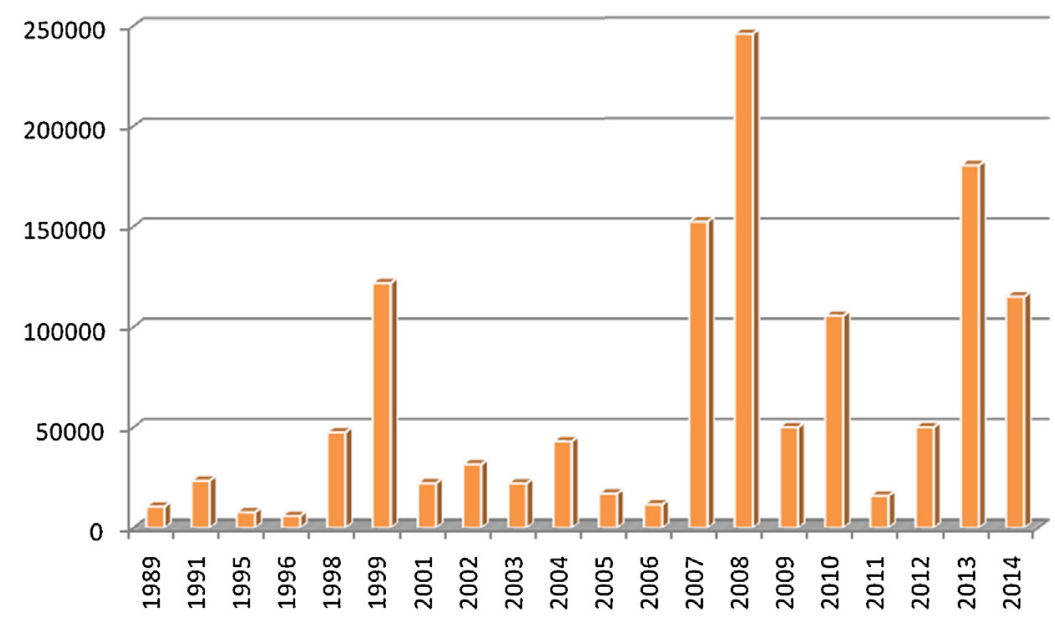

Fig. 7. Total gross leasable area $\left(\mathrm{m}^{2}\right)$ of shopping centres by opening year (Ankara) (current figures). Source: Authors' survey.

number of shopping centres, and their trade area also covers almost all districts. Research shows that in Ankara, suburban residents visit shopping centres more frequently, whereas inner-city residents visit shopping streets more frequently (Ozuduru et al., 2014).

The explosion in the number of shopping centres has had a significant impact on street retailers. In the early 2000s, most retailers in Ankara's CBD suffered because of the popularity of the new consumption spaces. Those still in business after the first wave of change survived because they adapted to the market conditions with innovative strategies. Their diversity, brand clustering, price ranges and selling specific goods and services have helped them remain afloat. The locational advantages of Ankara's CBD also help; there are still a significant number of residential units in the district, which includes a major transportation hub and a central area of high pedestrian traffic. The district's accessibility and high level of traffic increases its vitality, including its economic viability.

Ankara's CBD retailers have also been assisted by the municipality to some extent. The city has undertaken small restoration projects and increased the overall aesthetics in selected neighbourhoods. For

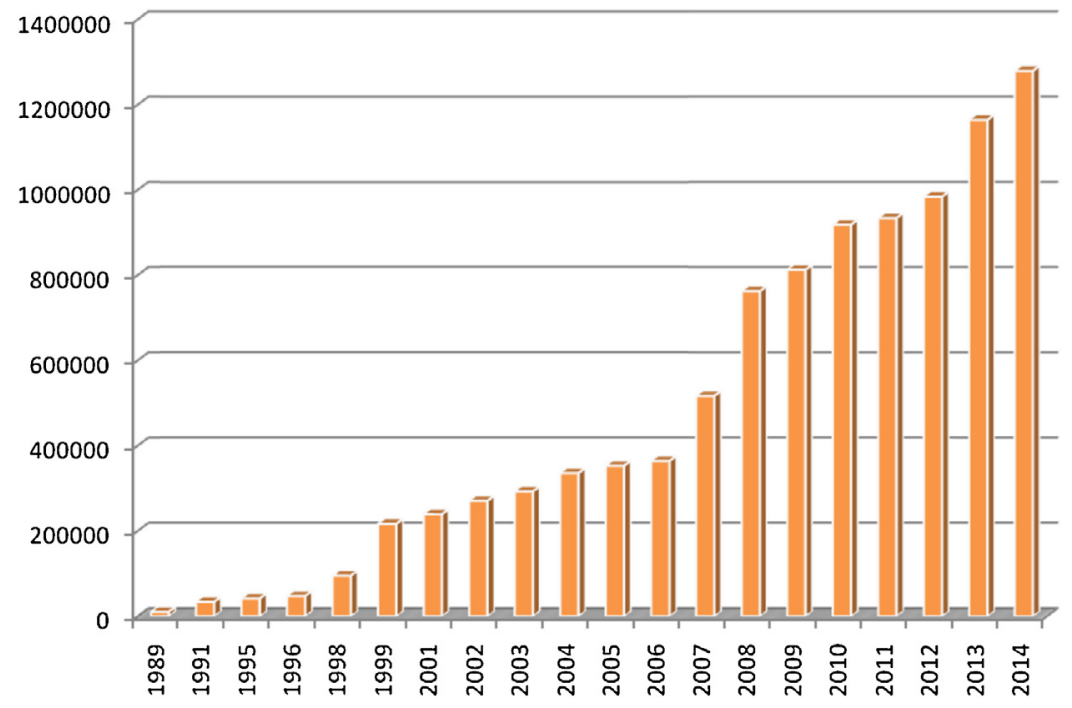

Fig. 8. Increase in total gross leasable area $\left(\mathrm{m}^{2}\right)$ of shopping centres by opening year (Ankara) (current figures). Source: Authors' survey. 
example, in Hamamonu (located in the historic area of the CBD), the municipality gentrified the neighbourhood by restoring and redeveloping the existing building stock and redesigning public areas. This change attracted new retail stores to supplement the existing cafes and restaurants, and the area has become a centre known for its eateries. Collaborating with local retailers in Kizilay (a part of the CBD of Ankara where traditional shopping streets dominate), the municipality improved the existing pedestrian area by installing urban furniture to make it easier for disabled citizens to access and enjoy the area. The common goal of such projects is to increase urban quality, and their impacts could be increased if they were part of a comprehensive urban plan that aimed to increase city centre vitality and viability.

In our analysis of retail development in Ankara, we relied on three extensive surveys. Two of these surveys focused on developments regarding global investments in shopping malls (Erkip \& Kizilgun, 2011; Ozuduru \& Varol, 2011) and the other focused on the impact of such developments on street retailing (Ercoskun \& Ozuduru, 2011).

The first project, which involved a detailed interview of retailers on one of Ankara's major shopping streets, was conducted between 2009 and 2011. It aimed at a comparative analysis of retail sector characteristics in Turkey and other European countries, in particular, Sweden, France and Portugal. The second project was also conducted between 2009 and 2011. It had several work packages, including in-depth interviews with retail organizations and prominent decision makers in the sector; detailed interviews with shopping centre customers; a quantitative analysis of the relationship between shopping centre supply and demand, using shopping centre attributes and customer characteristics in their trade areas and finally, urban policy development (Ozuduru \& Varol, 2011). The third project involved land use analysis of the major shopping streets in Ankara's CBD through in-depth interviews with the chamber of commerce, traditional retailers and the municipality, all of whom influence the revitalization plans and programmes of city centres. (Ercoskun \& Ozuduru, 2011).

We believe that the findings of these studies reveal many aspects of retail resilience, including influential factors on the strategies of small-scale, traditional retailers and shopping malls. The malls compete with each other and do not have serious competition from the small retailers, but the small retailers compete with the malls more than with each other. In fact, they have banded together to combat the malls. The actions of citizens and planning bodies were also analyzed in these studies in relation to selected European countries.
As Turkey's capital city since 1923, Ankara has been influenced by planning processes differently than other cities in Turkey. The share of public property ownership is relatively high in Ankara, and the transfer of rights has been from public to private in most cases. Local governments favour large capital and investments for urban rents, and much land that was formerly publicly owned has been privatized by local or central authorities and turned into large-scale real estate developments, including shopping centres.

With no comprehensive plan for Ankara between 1990 and 2007, urban development during that time was shaped by market mechanisms, with the number of shopping centres increasing. Despite the plan prepared in 2007, however, fragmented plans and plan modifications continue to dominate urban planning. Thus, shopping mall development in Ankara can be classified in accordance with (a) plan decisions, (b) plan changes, (c) urban redevelopment projects or (d) privatization decisions (see Table 4 for the development processes of existing shopping malls in Ankara).

Shopping malls developed in accordance with zoning plans are categorized under different functions; the current plan has no category involving malls. These sites, often large pieces of land, are usually suitable for urban public services, such as infrastructure, and for business districts that have been designated for those functions, but there is no law against them being used for commercial purposes and shopping mall development. Because of this situation, shopping malls on main arteries and on sites for urban services cause additional traffic load on these roads.

A significant number of malls are developed via plan changes or revisions. Although a development plan for Ankara was accepted in 2007, plan changes still occur; as indicated by Fig. 9, the highest number of plan changes occurred in 2008. Once a shopping centre development is approved, characteristics and measurements that may have been formerly forbidden, such as floor area ratio, height, etc., can also be changed. A plan change may include land use and physical changes to a building but does not alter the main principles of a development plan. A plan revision, however, results in changes to a plan's principles such as land-use decisions, development rights (floor area ratio, building height, etc.). Another development process incorporates the popular urban transformation projects that involve office space, residences and other project amenities along with shopping centres. These projects have become more popular since the changes in planning legislation that came into force after the 1999 Marmara earthquake, which resulted in many fatalities and much 
Table 4

Location choices and planning processes of shopping centres in Ankara.

\begin{tabular}{|c|c|c|c|c|c|}
\hline \multirow[t]{2}{*}{ Name of shopping centre } & \multicolumn{2}{|c|}{$\begin{array}{l}\text { Zoning according to development } \\
\text { plan }\end{array}$} & \multirow[t]{2}{*}{$\begin{array}{l}\text { Plan } \\
\text { changes }\end{array}$} & \multirow{2}{*}{$\begin{array}{l}\text { Urban } \\
\text { transformation } \\
\text { projects }\end{array}$} & \multirow[t]{2}{*}{ Privatization } \\
\hline & $\begin{array}{l}\text { Urban } \\
\text { employment/ } \\
\text { service area }\end{array}$ & $\begin{array}{l}\text { Partial } \\
\text { plans/plan } \\
\text { revisions }\end{array}$ & & & \\
\hline 365 & & $\mathrm{X}$ & & & \\
\hline Acity Outlet & $\mathrm{X}$ & & & & \\
\hline Akcenter & $\mathrm{X}$ & & & & \\
\hline Ankamall & & & $\mathrm{X}$ & & $\mathrm{X}$ \\
\hline Ankuva & & $\mathrm{X}$ & & & $\mathrm{X}$ \\
\hline Anse & $\mathrm{X}$ & & & & \\
\hline Antares & & & & $\mathrm{X}$ & \\
\hline Arasta AVM & $\mathrm{X}$ & & & & \\
\hline Arcadium & & & $\mathrm{X}$ & & \\
\hline Armada 1-2 & $\mathrm{X}$ & & $\mathrm{X}$ & $X$ & \\
\hline Atakule & & & $\mathrm{X}$ & & $\mathrm{X}$ \\
\hline Atlantis AVM & & & $\mathrm{X}$ & & $\mathrm{X}$ \\
\hline Bastim Podium AVM & & $\mathrm{X}$ & & & \\
\hline Beysupark AVM & & $\mathrm{X}$ & & & \\
\hline Bilkent Center & & $\mathrm{X}$ & & & \\
\hline Carrefour & $\mathrm{X}$ & & & & \\
\hline Cepa & $\mathrm{X}$ & & & & \\
\hline Etipark Outlet & $\mathrm{X}$ & & & & \\
\hline Forum Ankara & & $\mathrm{X}$ & & & \\
\hline FTZ & & $\mathrm{X}$ & & & \\
\hline Galleria & & $\mathrm{X}$ & & & \\
\hline Gimsa AVM & $\mathrm{X}$ & $\mathrm{X}$ & & & \\
\hline Gordion & & & $\mathrm{X}$ & & $\mathrm{X}$ \\
\hline Goksu Park AVM & $\mathrm{X}$ & & & & \\
\hline Karum & & & $\mathrm{X}$ & & \\
\hline KC Göksu & & $X$ & & & \\
\hline Kent Park & $\mathrm{X}$ & & & $\mathrm{X}$ & \\
\hline Kizilay AVM & & & $\mathrm{X}$ & & \\
\hline Mahall & & $\mathrm{X}$ & $\mathrm{X}$ & & \\
\hline Maksimum & & $\mathrm{X}$ & & & \\
\hline Malltepe Park & & & $\mathrm{X}$ & & $\mathrm{X}$ \\
\hline Mesa Plaza & & & $\mathrm{X}$ & & $X$ \\
\hline Millenium & $\mathrm{X}$ & & & & \\
\hline Mina Sera & & $\mathrm{X}$ & & & \\
\hline Next Level & $\mathrm{X}$ & & $\mathrm{X}$ & & \\
\hline ODC Centre & & $\mathrm{X}$ & & & \\
\hline Optimum & $\mathrm{X}$ & & & & \\
\hline Panora & & & $\mathrm{X}$ & & $X$ \\
\hline Park Vera & $\mathrm{X}$ & & & & \\
\hline Ustündekocity & $\mathrm{X}$ & & & & \\
\hline Taurus AVM & $\mathrm{X}$ & & $\mathrm{X}$ & & \\
\hline Tepe Prime & $\mathrm{X}$ & $\mathrm{X}$ & $\mathrm{X}$ & & $\mathrm{X}$ \\
\hline Vialife & $\mathrm{X}$ & & $\mathrm{X}$ & & \\
\hline
\end{tabular}

Source: Updated and modified version of Varol and Ozuduru (2010).

damage to buildings and infrastructure. The new legislation was designed to ensure that buildings can better withstand such disasters, thus many older buildings prone to damage have been demolished. Based on these changes, urban transformation legislation has favoured the large-scale mixed-use projects that include residences, shopping centres and other amenities. Fig. 10 shows Antares, one such project in Ankara.

One of the three noted surveys was carried out in 13 shopping centres with 2970 patrons and tallied the 


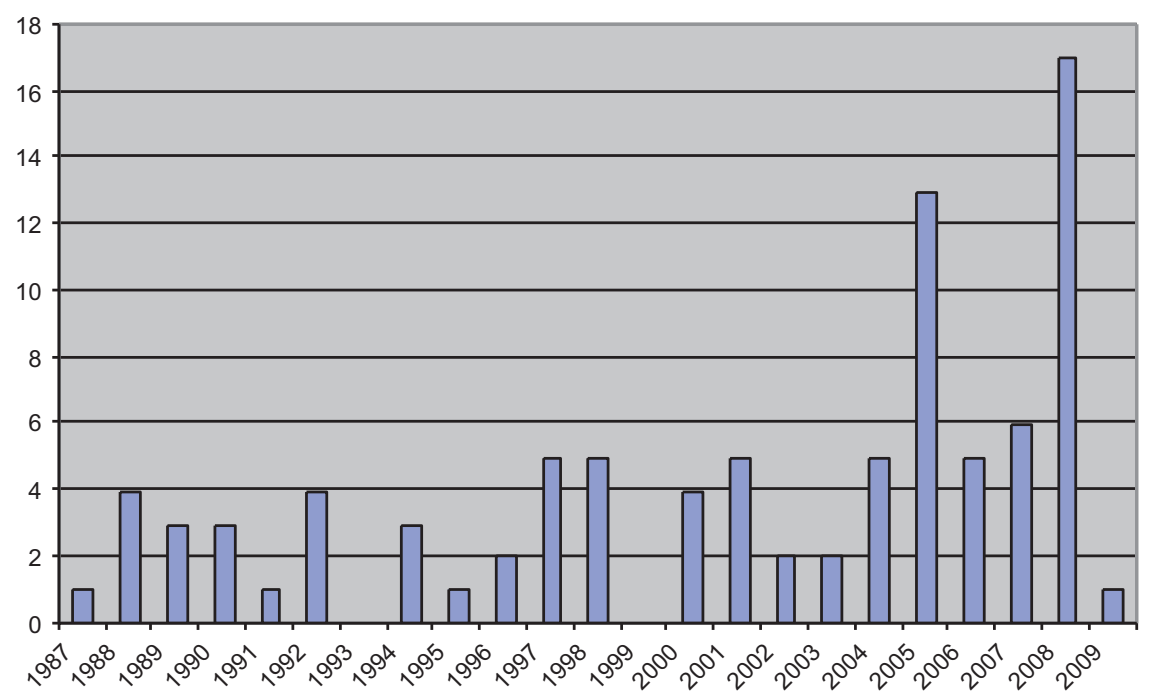

Fig. 9. The number of planning decision and plan changes pertaining to shopping centres by year. Source: Varol and Ozuduru (2010).

purposes of visits to shopping malls and streets (Ozuduru et al., 2014; see Table 5). The research shows that customers' reasons for shopping change in relation to the area they shop in. For shopping itself, people prefer shopping centres and shopping streets. For entertainment, strolling/window shopping, meeting friends and public transportation transfer, shopping streets are preferred significantly more than shopping centres. These findings show that shopping streets are used for more diverse purposes than shopping centres.

Table 6 shows the types of goods and services bought in shopping centres and shopping streets. The main purpose of shopping is to buy clothing/footwear and

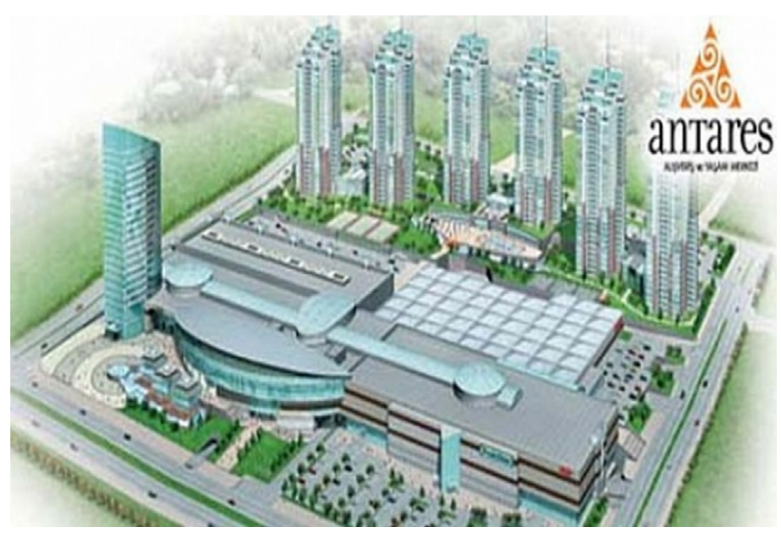

Fig. 10. Antares residences and a shopping centre.

Source: http://emlakkulisi.com/antares-avm-ankara-alisverisfestivaline-festival-agaligi-yapacak/ (accessed 15.01.14). accessories. However, shopping streets are preferred for groceries/supermarkets, technology products, theatres and other cultural activities. This finding reveals that shopping streets provide more-specialized goods and services than shopping malls.

It is an interesting observation that shopping streets are still an important venue for Ankara citizens, especially for socializing, entertainment and strolling. Younger citizens prefer visiting shopping streets because of other activities such as university preparation courses that are mostly located at the city centre and the relatively lower prices of goods and services. These areas seem to be able to compete with shopping malls in shopping as well, but both areas are used by various segments of society. Shopping street retailers in Ankara are more likely to specialize in particular goods and services, such as maintenance and repair of certain

Table 5

Comparison of visit purposes in shopping centres and streets.

\begin{tabular}{lll}
\hline Visit purpose & $\begin{array}{l}\text { Shopping } \\
\text { centre }(\%)\end{array}$ & $\begin{array}{l}\text { Shopping } \\
\text { street }(\%)\end{array}$ \\
\hline Shopping & 63.8 & 72.9 \\
Eating and drinking & 71.4 & 65.6 \\
Entertainment & 16.7 & 35.4 \\
Buying groceries & 30.0 & 33.8 \\
Strolling/window shopping & 59.0 & 74.5 \\
Meeting friends & 20.3 & 68.1 \\
Public transportation transfer & 0.0 & 23.0 \\
Other activities/facilities & 3.1 & 20.1 \\
\hline
\end{tabular}

Source: Ozuduru et al. (2014). 
Table 6

Shopping for goods and services in shopping centres versus shopping streets.

\begin{tabular}{lll}
\hline Goods and services & $\begin{array}{l}\text { Shopping } \\
\text { centre }(\%)\end{array}$ & $\begin{array}{l}\text { Shopping } \\
\text { street }(\%)\end{array}$ \\
\hline Clothing/footwear/accessories & 80.2 & 59.9 \\
Restaurants & 51.7 & 56.1 \\
Books/stationery & 36.4 & 38.4 \\
Groceries/supermarkets & 33.4 & 47.4 \\
$\quad$ Technology products & 25.6 & 40.7 \\
$\quad \begin{array}{l}\text { Theatres and other cultural } \\
\quad \text { activities }\end{array}$ & 21.0 & 42.3 \\
$\quad$ Furniture, kitchen appliances, & 1.9 & 31.3 \\
$\quad$ decor & & \\
$\quad$ Other (jewellery, exchange & 38.3 & 28.1 \\
$\quad$ offices, pharmacies, etc.) & &
\end{tabular}

Source: Ozuduru et al. (2014).

goods and domestic appliances. Clustering is another feature that has increased the resilience of shopping street retailers in Ankara (see Table 7). It is also apparent from Table 7 that Clothing/Shoes and Accessories/Cosmetics are the main retailing goods that sustain the economic vitality of shopping streets in Ankara. Jewellery/Gold/Currency Offices and Cafes/ Restaurants/Patisseries are other favourable retailing goods and services provided by shopping streets.

However, sometimes people prefer shopping malls to shopping streets for certain reasons or activities (see Table 8), such as cleanliness, diversity of stores, specific brands and stores, lower pricing, comfort level and atmosphere, accessibility, security, employee attitude

Table 7

Clustering of retail units according to prominent shopping streets in Ankara.

\begin{tabular}{|c|c|}
\hline Ataturk Boulvard & $\begin{array}{l}\text { Clothing/shoes accessories/cosmetics } \\
\text { jewelery/gold/currency }\end{array}$ \\
\hline Izmir Street & Clothing/shoes accessories/cosmetics \\
\hline $\begin{array}{l}\text { GMK } \\
\text { Boulevard-Ziya } \\
\text { Gokalp Street }\end{array}$ & $\begin{array}{l}\text { Clothing/shoes cafes/restaurants/ } \\
\text { patisseries }\end{array}$ \\
\hline Mesrutiyet Street & $\begin{array}{l}\text { Clothing/shoes cafes/restaurants/ } \\
\text { patisseries }\end{array}$ \\
\hline Necatibey Street & $\begin{array}{l}\text { Cafes/restaurants/patisseries technology } \\
\text { products and services } \\
\text { Books/journals/stationery }\end{array}$ \\
\hline Anafartalar Street & Jewelery/gold/currency clothing/shoes \\
\hline Tunalı Hilmi Street & $\begin{array}{l}\text { Clothing/shoes accessories/cosmetics } \\
\text { Cafes/restaurants/patisseries }\end{array}$ \\
\hline Arjantin Street & $\begin{array}{l}\text { Clothing/shoes cafes/restaurants/ } \\
\text { patisseries }\end{array}$ \\
\hline
\end{tabular}

Source: Ercoskun and Ozuduru (2011).
Table 8

Shopping centre characteristics by preference.

\begin{tabular}{lc}
\hline & Rank \\
\hline Cleanliness & 1 \\
Diversity of stores & 2 \\
Specific brands and stores & 3 \\
Lower pricing & 4 \\
Comfort level (restrooms, & 5 \\
air-conditioning, ATM, etc.) & \\
Atmosphere & 6 \\
Accessibility & 7 \\
Security & 8 \\
Employee attitude and knowledge & 9 \\
level & \\
Proximity to place of residence & 10 \\
Shopping, movie theatre and & 11 \\
recreation activities in one location & \\
Fast shopping & 12 \\
Diversity of eating and drinking places & 13 \\
Easily locating favourite store & 14 \\
Ease of parking & 15 \\
The hyper/supermarket & 16 \\
Concerts, exhibitions, etc. & 17 \\
Proximity to workplace & 18 \\
Ability to stroll with children & 19 \\
The do-it-yourself store & 20 \\
Activities for children & 21 \\
\hline Source: Oz &
\end{tabular}

Source: Ozuduru et al. (2014).

and knowledge level and proximity to place of residence. These qualifications show that the controlled and well-managed environments of shopping centres increase their attraction. The importance given to cleanliness and comfort might indicate the insufficiency of shopping streets in this regard. Many streets in Ankara suffer from a lack of maintenance and facilities, which negatively affects pedestrian traffic.

In an earlier empirical work (Ozuduru, 2013), the author found a significant relationship between the level of shopping centre supply and demand characteristics, particularly in relation to population, household income, age structure and education level. These demand characteristics in Ankara have been spatially analyzed (Ozuduru \& Varol, 2011; Ozuduru et al., 2014) and the findings show that shopping centre locations are specified in relation to these characteristics. For example, Ankara's southern and southwestern neighbourhoods are populated with higher shares of highincome households, and the western part is populated with higher shares of middle-income households. As observed in Fig. 11, shopping centres are located in proximity to these households. The number of shopping centres on the northern and eastern parts of Ankara is significantly low. 


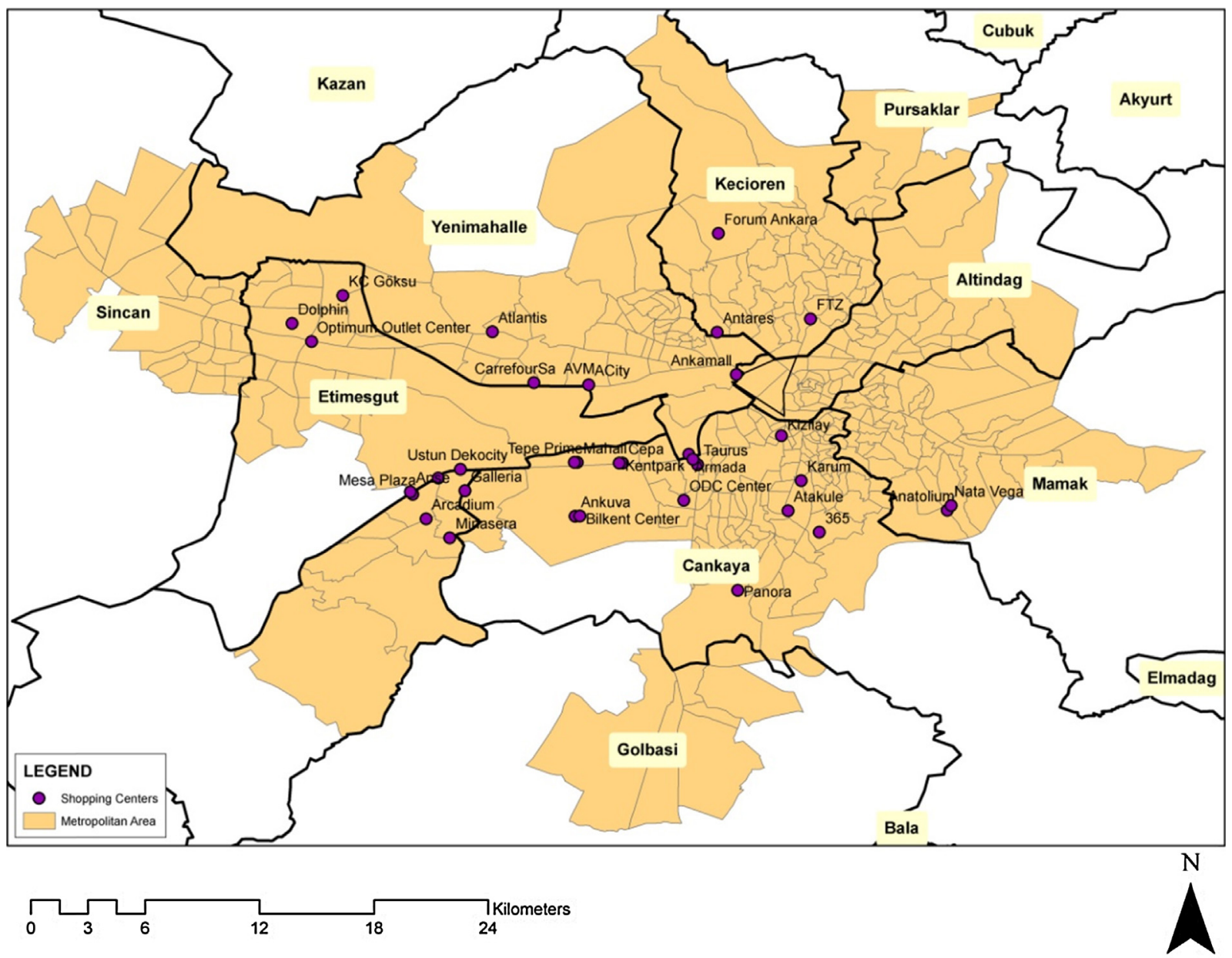

Fig. 11. Locations of shopping centres in Ankara (2013).

Source: Authors' Search (2013).

Fig. 11 shows the locations of shopping centres in Ankara as of 2013, when the number of shopping centres increased significantly to 37 from 29 in 2010. Fig. 12 shows the distance to shopping centres from different areas of Ankara. It illustrates that the western and southwestern parts of the city, where the share of upper-middle and middle-income residents is high, are amply supplied by shopping centres. The road network also shows that some areas are more accessible than others, mainly due to the locations of suburban development and the high accessibility of these areas by car. Research shows that people living in suburbs mostly commute by car and prefer shopping centres to shopping streets (Ozuduru et al., 2014).

Street retailers (209) were also surveyed to understand their opinion about shopping mall influence on shopping streets and for suggestions on how to make their streets more resilient and appealing. According to those retailers (Ercoskun \& Ozuduru, 2013), lack of sufficient parking is the highest concern. Other important concerns are the insufficient regulation and limitation of shopping centres and limited provision of subsidy (tax incentives and credit) options to street retailers (see Table 9 for the other issues raised).

In another study (Erkip \& Kizilgun, 2011), 27 retailers were interviewed on two adjacent streets. The purpose of the study was to reveal the impacts of shopping mall development on street retailers and how that varied depending on the composition of retail mix and consumer characteristics. One of these streets is a traditional shopping street appealing mostly to middleincome earners and one is a high street appealing to higher-income and more-educated groups; each hosts many retailers. Both streets are quite old, and rich in retail variety. The traffic flow on both streets has been one-way for the last few years, which has caused 


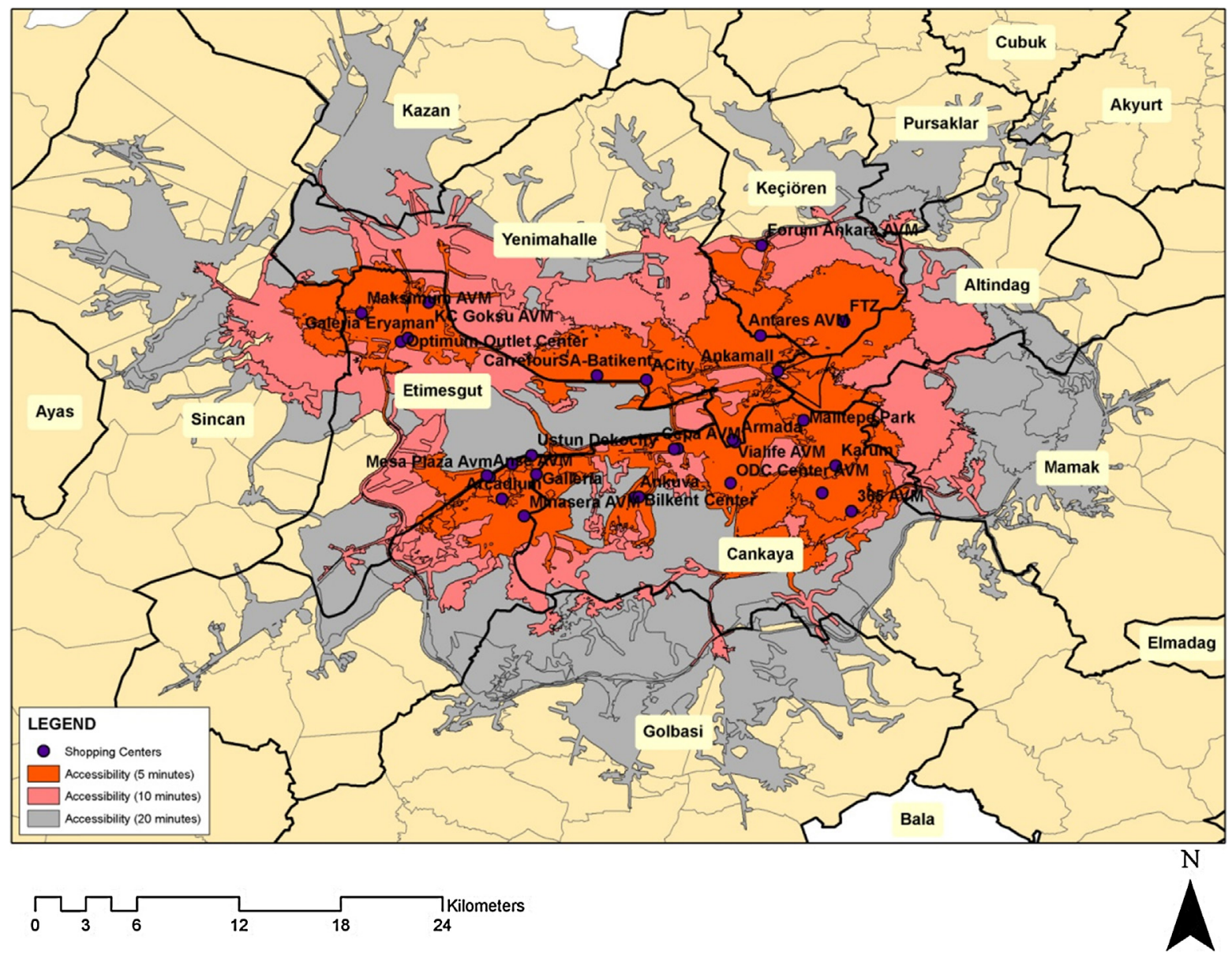

Fig. 12. Accessibility of shopping centres in Ankara (5, 10 and $20 \mathrm{~min}$ ).

Source: Ozuduruand Varol (2011).

problems for the retailers. The interviews indicated that traffic load and parking problems are major detriments to business. Other complaints concerned shopping mall competition and the lack or insufficiency of municipal services, such as infrastructure, street furniture and lighting. High-street retailers have more concerns about citizen responsibility for making their street livelier and increasing the appeal of the street, but all street retailers have similar concerns and complaints regardless of their shop location. The findings show that retailers' issues are not limited to the threat caused by shopping mall development.

In fact, land use analyses of the most prominent shopping streets in Ankara reflect that they have a high level of resilience, despite their traffic problems (Ercoskun \& Ozuduru, 2011). The pedestrianized roads in Kizilay, Ankara's most central district, seem to be the most lively areas for shopping visits, especially for young people. All types of products are sold in various qualities on these streets, which is a reason for the area's resilience. Ulus, the former core of Ankara, is a tourist destination due to its historical importance. The stores in this area specialize in jewellery, gold and foreign currency exchange, as well as technology products such as cell phones. The products here are relatively cheaper than other shopping streets, a feature that makes the area attractive for lower-income groups and more traditional segments of society. The last area, Kavaklidere, consists of two high streets, with the older one, Tunali Hilmi, featuring attractive stores and modern, European-style coffee shops. The field survey done through a detailed questionnaire indicated that visitors to this street belong to higher-income and more-educated segments of society (see Erkip et al., 2013 for the details of the survey); they visit the street a few times a week, which shows the popularity of it among this group. Although the area suffers from heavy traffic, it has two major advantages: a large established park and Ankara's first 
Table 9

Retailers' perspectives on increasing the utilization of shopping streets.

\begin{tabular}{|c|c|c|c|c|c|c|}
\hline $\begin{array}{l}\text { What should be done to improve the } \\
\text { shopping street on which your retail } \\
\text { unit is located? }\end{array}$ & $\begin{array}{l}\text { 1. Definitely } \\
\text { agree }\end{array}$ & 2. Agree & $\begin{array}{l}\text { 3. Partially } \\
\text { agree }\end{array}$ & $\begin{array}{l}\text { 4. Don't } \\
\text { agree }\end{array}$ & Total & $N$ \\
\hline Regulate and limit shopping centres & $62.7 \%$ & $31.6 \%$ & $0.5 \%$ & $5.3 \%$ & $100.0 \%$ & 209 \\
\hline $\begin{array}{l}\text { Provide subsidy (tax incentives and } \\
\text { credit) options to street retailers }\end{array}$ & $53.6 \%$ & $42.1 \%$ & $2.9 \%$ & $1.4 \%$ & $100.0 \%$ & 209 \\
\hline Decrease vehicle traffic & $38.8 \%$ & $29.2 \%$ & $16.3 \%$ & $15.8 \%$ & $100.0 \%$ & 209 \\
\hline Expand and redesign sidewalks & $26.3 \%$ & $37.3 \%$ & $21.5 \%$ & $14.8 \%$ & $100.0 \%$ & 209 \\
\hline Increase the number of parking lots & $70.8 \%$ & $22.5 \%$ & $4.8 \%$ & $1.9 \%$ & $100.0 \%$ & 209 \\
\hline Pedestrianize shopping streets & $23.4 \%$ & $29.7 \%$ & $12.4 \%$ & $34.4 \%$ & $100.0 \%$ & 209 \\
\hline Increase the diversity of retail units & $21.5 \%$ & $34.9 \%$ & $35.4 \%$ & $8.1 \%$ & $100.0 \%$ & 209 \\
\hline $\begin{array}{l}\text { Increase green areas around } \\
\text { shopping streets }\end{array}$ & $23.9 \%$ & $54.1 \%$ & $17.2 \%$ & $4.8 \%$ & $100.0 \%$ & 209 \\
\hline Increase security & $27.3 \%$ & $31.1 \%$ & $28.2 \%$ & $13.4 \%$ & $100.0 \%$ & 209 \\
\hline $\begin{array}{l}\text { Increase the quality of eating and } \\
\text { drinking places }\end{array}$ & $25.4 \%$ & $35.9 \%$ & $34.9 \%$ & $3.8 \%$ & $100.0 \%$ & 209 \\
\hline $\begin{array}{l}\text { Increase the amount of street } \\
\text { furniture (seating areas, lighting, } \\
\text { sculptures, etc.) }\end{array}$ & $17.3 \%$ & $22.1 \%$ & $54.3 \%$ & $6.3 \%$ & $100.0 \%$ & 208 \\
\hline
\end{tabular}

Source: Ercoskun and Ozuduru (2013).

shopping mall (built in 1989). Arjantin, the second high street in this area, was developed as a continuation of the first street and features many stores selling branded clothes, which also makes it attractive to higher-income citizens. The historical development of Ankara's shopping streets also highlights that new shopping streets did not cause others' decline; all shopping streets have survived by targeting different customers and developing resilience strategies. Ankara's increase in population and disposable income also supported their viability, despite unfair competition from large-scale retailers and shopping malls.

\section{Retail planning in European countries: lessons to be learned}

In this section, we document the retail planning policies and strategies of some European countries as a basis for comparison with the Turkish situation. Considering that there is no nation-wide retail policy or legislation in Turkey, public organizations and financial institutions act independently and according to global and local economic conjectures. Further, a lack of modern public spaces helps increase the appeal of shopping malls. Compared to other European countries and the US, where young people prefer shopping malls over street retailers, young people in Turkey frequently visit street retailers (Ercoskun \& Ozuduru, 2011). The central location of many malls in Turkish cities makes them more accessible, but also increases traffic load in the urban core. Having retail planning linked to urban planning would help prevent such situations from occurring. Evaluating the findings of the Urban-Net Project called "Retail Planning for Cities' Sustainability" (REPLACIS), Barata-Salgueira and Erkip (2014, p. 110) claim that "it is possible to find some commonalities in policies adopted in different countries and cities, but public policy also displays much specificity, with, for example, different impacts on land use and the livability of shopping districts."

Ozcan (2000) notes that the Turkish experience of retail change is similar to that of Greece and Portugal. Tokatli and Boyaci (1998) consider Hungary and Poland similar cases to Turkey. Franz et al. (2013) also suggest that Turkey's experience resembles Central European countries. We rely mostly on the findings of the REPLACIS project to discuss retail planning in Sweden, France, Portugal and Turkey.

Karrholm and Nylund (2011, p. 1044) argue that planning efforts in Europe focus on policies against peripheral retail developments. They further state that "the European research on retail planning has been investigating and comparing different policies on offcentre retailing, for example in the UK, Germany, France and the Netherlands....in some countries, planning regulations are tightened, while other countries still seem to trust in the force of regulation by market mechanisms."

Interestingly, Turkey is not the only country dealing with problems pertaining to retail planning. Despite its 
strong urban planning tradition, Sweden also lacks a comprehensive retail policy; local governments tend to tolerate retail development because it increases competition between municipalities to supply better services to attract retail investments. However, because regional planning is weak, retail organizations seem to control retail development (Replacis, 2011); Turkish retail planning seems to be experiencing a similar bottleneck. Recently, representatives of private and public sectors and planning bodies have established coalitions to develop alternative visions for Sweden's retail sector. As the main problem in Sweden is competition between adjacent municipalities, Karrholm and Nylund (2011) suggest that the regional level would be more appropriate to cope with this situation. Regional planning would need to be powerful enough to control and coordinate local retail investments to provide more effective land development and solutions to environmental problems. Environmental sustainability is one of core concepts in Swedish planning and this aspect should be taken more seriously in considering retail investments in Turkey.

The resilience of French cities is reflected in area revitalization projects. These areas are not necessarily former or declining shopping streets; industrial and agricultural lands and harbours are also becoming sites for new retail businesses in urban cores. Such overhauls include a comprehensive policy on traffic regulations, public transportation and pedestrian areas. Although these approaches are systematic, they are mostly applied in small-scale cities. For that reason, the French case does not provide too many clues for Turkish retail development and planning. Some recent projects can help plan for projects of a similar size in Turkey, yet it is difficult to derive general conclusions for larger cities.

The experience of Portugal is valuable for Turkey, as it shows ways of utilizing EU funds for retail planning. Beginning in 1994, EU funds were used to develop and modernize urban cores, retail businesses and public spaces through a commercial urbanization programme (PRO$\mathrm{COM}$ ) that encouraged public-private collaboration between retailers and local authorities (Replacis, 2011). A successful regional planning policy guided retail investments via proper allocation of funds and helped revitalize urban cores and support small- and mediumscale retailers with credit options. The main components of this approach persisted until 2006, after which point legislation, financial incentives and ecological assessments of the modernization projects were introduced (Replacis, 2011). However, the 2008 financial crisis, which greatly affected Portugal, created serious setbacks in economic development and retail planning there.
The example of retail development in the UK also offers interesting information for Turkey because it seems to be following a similar path. Large-scale retail outlets in the UK appeared in the 1970s. The UK supermarkets gained power and then used that power to influence local authorities. In the 1990s, the UK's Thatcher government adopted a rather liberal approach to retail planning to deal with increasing globalization of the retail markets. However, this decision had a negative impact on traditional/local retailers located in major city centres, such as Cardiff (Guy, 1996). The number and diversity of local retailers have decreased significantly in the UK, as has the quality of urban spaces in inner city neighbourhoods. As governing bodies have become aware of the economic problems of urban retailers and the changing nature of public spaces, they have begun to implement urban policies, such as prohibiting out-of-town centre developments to prevent the negative impact of such developments. Public authorities began focusing on the economic stability of town centres.

The UK's new retail policy guidelines were introduced in the 1990s, which explained the benefits of development in town centres and the need for sustaining a balance between in-centre and out-ofcentre developments. It also underlined the importance of accessibility of new developments by all modes of transportation, hence decreasing private car demand (Guy, 2007). In 1994, a new policy approach called the 'sequential test' was adopted, stating that developers could consider investing in out-of-town developments only if there were no suitable sites in town. Through the end of the 1990s and the beginning of the 2000s, UK urban policy guidelines were 'tightened up' to eliminate ambiguities and weaknesses. Their main goals were to decrease private vehicle trips, eliminate the negative impact of urban growth on city centres and on the urban economy and preserve the natural environment and cultural heritage. By 2004, retail and urban policies had been revised to allow retail-led urban regeneration projects and programmes (Guy, 2007).

Although the economic and cultural conditions of the above-noted countries are different from Turkey's, some aspects of their policies can be utilized to help Turkey develop a holistic retail development policy, considering that the country experienced shopping mall development and EU membership prospects later than the other countries discussed in this paper. Although the field surveys cited in this study reveal that shopping streets are more resilient in Turkey than in other countries, these findings do not mean that they will survive forever. Considering that shopping malls are 
more central in Turkish cities than in other cities in the Europe-area, the decay in first-generation malls may influence the surrounding areas and cause a decrease in the areas' appeal and in the appeal of independent retailers and streets. It is still early in the Turkish case to expect that this situation might lead to an enhancement in the use of shopping streets and public spaces.

There are serious restrictions on shopping centre locations in European countries. Before deciding to build a shopping centre, investors carry out various market analyses around population density, income level, average rent level, investment periods, transportation opportunities and traffic loads. Discouraging or forbidding large capital from investing in city-centre protects street retailers and the urban core. In Turkey, however, strategic urban areas have been increasingly privatized and transferred to investors due to local governments' limited control over such transactions.

\section{Concluding remarks: implications for the future of retail planning in Turkey}

In Turkey, shopping mall development has become physical evidence of the political party in power, particularly after the construction sector boom started in 2004. Today, the government regards shopping centre investments as among their major successes and as a display of their interest in urban areas (including various megaprojects (www.megaprojeleristanbul.com) of which shopping malls are major parts). "The current Islamic bourgeoisie and the business elite of Turkey are integral to the investments and partnerships of the multinational capital in large shopping malls, luxurious hotels and modern residential complexes" (Moudouros, 2014, p. 189). The question is how long this situation will last with the prevailing uncertainties in the sector in particular and in the country in general.

Urban policymakers around the world are trying to strengthen retail markets in inner-city neighbourhoods. One approach is to promote new retailing models. Most revitalization strategies acknowledge that mass retailing is not essential for downtowns, and many municipalities built festival marketplaces in urban cores in the 1970s and early 1980s. A high share of festival centre space is devoted to specialty restaurants and food vendors. In such areas, retail stores tend to count on people impulse buying specialty items. A strong entertainment theme is often present, with regular informal events featuring mimes, jugglers, dancers, strolling musicians and others (Beyard \& O'Mara, 2005). These venues are heavily dependent on tourists and offer a unique shopping experience, thus attracting repeat customers
(Barata-Salgueira \& Erkip, 2014). In the 1980s and 1990s, a few small-scale shopping centres were built in downtown areas, with the aim to generate a vitality that would positively influence local retailers. These malls encouraged shoppers to visit other downtown stores and restaurants, creating additional jobs and sales tax revenues, and restoring social and community spirit (West \& Orr, 2003). Jones and Hillier (2000) show that retail-led urban regeneration programmes can be helpful because they serve as catalysts for the (re)development of town centres; most businesses act and think more creatively when local governments implement such programmes. These initiatives usually include physical, economic and social interventions, such as improving curb appeal, providing land for new or relocated activities, creating employment opportunities and building community facilities. The UK experience shows that such plans and projects can also help increase resilience in city centres.

In Turkey, local governments (who should be responsible for urban development, including location decisions of commercial sites and shopping mall development control in accordance with population growth and demand) have been ineffective in guiding supply and investment. Contrary to many foreign examples, Turkish governments are concerned more about the short-term economic benefits of such developments and have neglected to consider the long-term ramifications. This lack of holistic planning both in terms of urban development and the retail sector has left Turkish cities vulnerable to market forces. In closing, we point out issues that should be considered and resolved by interested parties and authorities in Turkey.

\subsection{Regulation of the relationship between large- scale and traditional retailers}

In Turkey, retail regulations do not exist, and therefore do not protect traditional retailers. The legislation cedes control to market dynamics. Small sector actors are thus vulnerable to economic fluctuations, and survive partly through informal social networks. Customer loyalty, placement on major streets, inclusion in broader personal networks (based on ethnicity, religion, etc.) help these retailers to be more resilient. The legal framework and the government should provide new ways to advance business. In addition to developing a comprehensive plan to outline the relationship between demand and supply, a new approach that would enforce the increased utility of traditional retailers should be suggested. While regeneration projects in older retail areas should continue to 
be encouraged, they require a more planned and coordinated approach.

Shopping streets are an important part of cities' livelihoods. Many countries experience decay in the urban core due to sprawl and mall development. Regeneration and revitalization projects can be applied in such cases. Turkish cities have lively urban cores despite the transformation in the country's retail sector; governments need to ensure this situation continues by supporting and planning for it. Such planning will also help mitigate major and minor crises in the economy.

\subsection{Provision of definitions and standards}

In Turkey, commercial sector definitions and standards are neither specific nor linked with development plans. In other words, definitions such as central business district, strategic sub-centre, retailer (grocery, patisserie, butcher, crafter, hairdresser, etc.) and shopping centre (super regional, regional, community centre, etc.) types are not classified, and thus not included as part of development plans, nor are they in the legislation that does exist. Indicators and criteria for evaluation should be developed in a sector analysis. Creating such definitions and standards will help specify the roles of these land uses in urban plans and how a retailer or centre should be considered in relation to its size, attraction level and impact. Having these guidelines in place will enable a better framework for legislation, and provide a road map to increase the resilience of commercial areas. Retailers' levels of service should also be considered. In the current legislation, only the size of the centre/retailer matters; but size is only one factor to be considered when planning where to locate a business: population, attraction level, car ownership in the area and relationship to existing and planned retail development are other factors to think about. Data collection and more effective use of public agencies to monitor the market's actions should also be enforced; such practices will significantly contribute to the sector's progress. Existing figures and data are neither systematic nor complete.

\subsection{Rule set-up for site-selection feasibility analyses and relationships to development plans}

Undertaking feasibility analyses in selecting sites for significant land uses is important in urban policymaking to help determine the potential impact on the environment and on existing land uses. For example, the role of shopping centres in transportation plans and in traffic and environmental pollution has been ignored in Turkish law, thus is not effectively managed. Rules and regulations regarding CBD management have been similarly ignored, thus the concerns of independent traditional retailers are also not considered. Development plans are tools of control. They specify structure, population, traffic density, small- and medium-scale business operations, public utility, compatibility with the built environment and the need for incorporating scientific evaluations into feasibility analyses. Turkish legislation is very pliable; as our study revealed, rules and regulations are easily changed.

\subsection{Arrangement of the roles of public and private actors in the development process}

The roles of government organizations in the Turkish retailing system remain obscure because central authorities and local municipalities alike can influence the shopping centre development process. In a similar fashion, traditional retailers can be registered in a chamber of commerce or in a retailer confederation. This situation makes it difficult for retailers to determine who is in charge of business plans and programmes. Turkish municipalities should consider how to improve the conditions of traditional retailers via urban interventions. For example, pedestrianization, traffic control and quality of public spaces can be regulated by local governments. Municipalities should also offer ways to increase the service quality of local retailers, educate them on various technological advancements and provide business strategies on survival tactics in a competitive retail atmosphere.

The role of private actors should also be scrutinized in the legislation. The level of power held by shopping centre investors, developers and managers in Turkey affects the dynamics of urban development. Some limitations should be suggested and applied to allow increased advocacy by vulnerable groups, such as traditional retailers. The lack of NGO initiatives and citizen participation in retailing is another persistent problem. This situation means there is little means of opposing blanket decisions by governments and powerful interest groups. The Turkish political environment seems to prevent such voluntary organizations of citizens and small-scale retailers from being active in the negotiation process, making them vulnerable in the current surge of large investments aiming to commodify urban spaces. 
Our research findings indicate signs of citizens' increasing interest in decisions made about public urban spaces, such as in claiming ownership by protesting against central and local governments' land use policies. Turks' extensive use of open public spaces, such as parks and streets, also shows the potential for combining traditional and modern forms of urban life without much effort. This fact may be the place from which to begin developing inclusive policies about public spaces and streets, and by including all parties concerned: citizens, traditional retailers, street vendors, local NGOs and government. Now is the time to consider this opportunity for making urban areas in Turkey lively and livable by all segments of society. Such initiatives may also help prevent the standardization of commercial areas that results in limited patterns of daily urban life. Maintaining the resilience of shopping streets is a vital part of this transformation.

Although in this paper we did not particularly focus on the use of public spaces, extensive street use is a key factor in the use of other public spaces, such as parks and recreational areas. Our research indicates that streets and parks are used especially when they are well maintained. An urban park adjacent to a shopping street results in a more positive perception of the street (Erkip et al., 2014). The young population of Turkish cities shows that there is a desire and an advantage to improving public spaces in the urban core; local governments should acknowledge the demand for public services instead of approving more shopping malls.

We predict that shopping malls will evolve to be more segregated in their choices of location and tenant mix, where some of them become more willing to invite domestic brands, thanks to increasing competition, economic volatility and changing demand structure. The example of "tesettur giyim" reflects that shopping mall developers' only concern is economic stability and that the source of that stability does not much matter; they try to measure changes in demand and adapt accordingly. This approach is the dominant resilience strategy of large-scale retail investments. From a sociological point of view, this strategy may result in increased tolerance among various consumer groups with opposing worldviews, but at the opposite extreme, it may result in more segregation, in line with the increasing tension on Turkish streets, if the current political unrest continues; during the Gezi Park events, protests extended to some high-end shopping malls in Istanbul (Milliyet Gazetesi, 2013). It should not come as a surprise, then, if a debate on the public use of shopping malls for political action is a part of future shopping mall development. It is also expected that surveillance in malls would be justified and increased in reference to threats to security on the streets.

Such macro-level changes in Turkey's political, economic and social environments are most likely to define its urban environment in the near future. Although it seems that TNCs still find Turkey attractive for retail investments, they have begun to be more cautious in recent years, especially since 2010. Retail actors who lack institutional support are also threatened by these changes. Under such uncertainties, "bouncing forward" (Shaw, 2012) may not happen. As he rightly states, "there is still much empirical work to be done on how effective leadership for resilience can be further developed, how professionals can best learn about resilience, and how the appropriate balance between organizational resilience and other types of resilience (such as those operating at the level of the community or individuals) can be operationalised" (p. 310). Thus, the initiatives of small-scale retailers need to be guided by a leadership that stems from national and regional retail policies. An accumulation of spontaneous responses, which seems to be the case so far, does not add up to a holistic solution for a resilient system. The spatial imprints of individual resilience strategies, which cause a fragmented urban environment, can incrementally build up into chaos - as the current situation indicates in Turkey.

\section{References}

Association of Shopping Centers and Retailers. (2010). Parlayan Yildiz: Perakende Sektorunun Turk Ekonomisine Etkileri [The Shining Star: Impacts of The Retail Sector Turkish Economy]. http://www.ampd.org (accessed 17.12.12).

Ankara Development Agency. (2011). Istatistiklerle Ankara (Ankara by Statistics). Ankara Kalkinma Ajansi Araştirmalar Serisihttp:// www.ankaraka.org.tr/tr/files/yayinlar/istatistiklerle-ankara-2011. $p d f$ (accessed 29.12.13).

Ankara Greater Municipality. (2007). 2023 Baskent Ankara Nazim Imar Plani Aciklama Raporu. 2023 Development Plan Report of the Capital City Ankara]. Ankara: Fersa Matbaacilik.

Kearney, A. T. (2013). Global Retail Development Indexhttp://www. atkearney.com.

Kearney, A. T. (2012). Global Retail E-Commerce Indexhttp://www. atkearney.com.

Babalik-Suttcliffe, E. (2013). Urban form and sustainable transport: Lessons from the Ankara case. International Journal of Sustainable Transportation, 7(5), 416-430.

Banerjee, T. (2001). The future of public space: Beyond invented streets and reinvented places. Journal of American Planning Association, 67(1), 9-24.

Banister, D. (1997). Reducing the need to travel. Environment and Planning B: Planning and Design, 24(3), 437-449. 
Barata-Salgueira, T., \& Erkip, F. (2014). Retail planning and urban resilience: An introduction to special issue. Cities, 36, 107-111.

BBCNews. (2014). DirenAmasya-Turkey's Latest Gezi-Style Protesthttp://www.bbc.com/news/blogs-trending-27700981 (accessed 06.06.14).

Bernstein Research Call. (2005). Not in my backyard: Community opposition to big box retail in the United States. Black book-Long view: 2005 Edition-U.S. Perspectives (pp. 7-14)Bernstein Research LLC. www.webcitation.org/6Q286EZTF (accessed 02.06.14).

Beyard, M. D., \& O’Mara, W. P. (2005). Shopping center development handbook (3rd ed., Second Printing). Washington, DC: The Urban Land Institute (ULI).

Bromley, R. D. F., Tallon, A. R., \& Thomas, C. J. (2005). City centre regeneration through residential development: Contributing to sustainability. Urban Studies, 42(13), 2407-2429.

Retail planning and urban resilience [special issue]. (2014, February). Cities, 36, 1-210.

Congress for the New Urbanism (cnu.org). (2007). Micro Retail at Belmarhttp://www.cnu.org/resources/imagebank/ micro-retail-belmar (accessed 15.01.14).

Collier, M. J. et al. (2013). Transitioning to resilience and sustainability in urban communities. Cities, 32(Suppl. 1), 21-28.

Cummings, G. S. (2011). Spatial resilience in social ecological systems. Dordrecht: Springer.

Cushman \& Wakefield. (2012, September). A global perspective on the shopping center industry.

Cushman \& Wakefield. (2013, July). Global perspective on retail: Online retailing.

Cushman \& Wakefield. (2013/2014). Main Streets Across the World.

Cushman \& Wakefield. (2013, May). Marketbeat, Shopping Centre Development Report: Europe.

Davoudi, S. (2012). Resilience: A bridging concept or a dead end? Planning Theory and Practice, 13(2), 299-307.

Deloitte and Planet Retail. (2010). Hidden heroes emerging retail markets beyond China.

Economist Intelligence Unit. (2009, March). Industry report - Consumer goods and retail Turkey.

Economist Intelligence Unit. (2013). Industry report - Consumer goods and retail Turkeyhttp://country.eiu.com/article. aspx?articleid=1890907773 (accessed 11.11.13).

Ercoskun, O. Y., \& Ozuduru, B. H. (2013). Alisveris Mekânlarındaki Degisimin Sosyal Sürdürülebilirlige Etkisi: Ankara Ornegi, TMMOB Sehir Plancilari Odasi Ankara Subesi Yayini, Ankara.

Ercoskun, O. Y., \& Ozuduru, B. H. (2011). Alisveris Mekanlarindaki Degisimin Sosyal Surdurulebilirlige Etkisi: Ankara Ornegi, 109K325 nolu 1002 Hizl Destek Programi tarafindan desteklenen proje raporu, Tubitak, Sobag, Ankara.

Erkip, F. (2003). The shopping mall as an emergent public space in Turkey. Environment and Planning A, 35, 1073-1093.

Erkip, F. (2005). The rise of the shopping mall in Turkey: The use and appeal of a mall in Ankara. Cities, 22, 89-108.

Erkip, F., Kizilgun, O., \& Mugan Akinci, G. (2013). The role of retailing in urban sustainability: The Turkish case. European Urban and Regional Studies, 20(3), 329-342.

Erkip, F., Kizilgun, O., \& Mugan Akinci, G. (2014). Retailers' resilience strategies and their impacts on urban spaces in Turkey. Cities, 36, 112-120.

Erkip, F., \& Kizilgun, O. (2011). Kentlerin Surdurulebilirligi icin Perakende Sektorunun Planlanmasi, 108K614 nolu 1001 Bilimsel ve Teknolojik Arastirma Projelerini Destekleme Programi tarafindan desteklenen proje raporu, Tubitak, Sobag, Ankara.
Evans-Cowley, J. S. (2005). Regulatory strategies for big-boxes. Zoning Practice, 22(12), 1-7.

Foster, K. A. (2007). Snapping back: What makes regions resilient? National Civic Review, 96(3), 27-29.

Franz, M., Appel, A., \& Hassler, M. (2013). Short waves of supermarket diffusion in Turkey. Moravian Geographical Reports, 21(4), 50-63.

Garreau, J. (1992). Edge city: Life on the new frontier. New York: Doubleday Dell Publishing Group Inc.

Ghosh, A., \& McLafferty, S. L. (1987). Location strategies for retail firms and service firms. Lexington, DC: Heath Company.

Gurkaynak, R. S., \& Sayek-Boke, S. (2013). AKP Doneminde Turkiye Ekonomisi. Birikim, 296, 64-69.

Guy, C. M. (1996). Corporate strategies in food retailing and their local impacts: A case study of Cardiff. Environment and Planning A, 28(9), 1575-1602.

Guy, C. M. (1998). Controlling new retail spaces: The impress of planning policies in Western Europe. Urban Studies, 35(5-6), 953-979.

Guy, C. M. (2007). Planning for retail development. New York: Routledge.

The Association of Real Estate and Real Estate Investment Companies. (2008). Turkiye'de Perakende Pazari ve Alisveris Merkezleri için Ongoruler 2015. Forecasting for Retail Market and Shopping Center in Turkey 2015]. İstanbul: GYODER.

Geyikdagi, V. N., \& Geyikdagi, M. Y. (2009). Liberalization in Turkey: Does history repeat itself? Middle Eastern Studies, 45(1), 71-86.

Ibrahim, M. F. (2002). Disaggregating the travel components in shopping center choice: An agenda for valuation practices. Journal of Property Investment and Finance, 20(3), 277-294.

Istanbul'un Megaprojeleri official website, http://www. megaprojeleristanbul.com/ (accessed 09.12.13).

Jones, P., \& Hillier, D. (2000). Changing the balance: The ins and outs of retail development. Property Management, 18(2), 114-126.

Karrholm, M., \& Nylund, K. (2011). Escalating consumption and spatial planning: Notes on the evolution of Swedish retail spaces. European Planning Studies, 19(6), 1043-1059.

Knox, P. L. (2008). Metroburbia, USA. New Brunswick, NJ: Rutgers University Press.

Kursunluoglu Yarimoglu, E. (2014). Turkish retail industry and the relations with Albania [special edition]. European Scientific Journal, 1, 114-124.

Lang, R. E. (2003). Edgeless cities: Exploring the elusive metropolis. Washington, DC: The Brookings Institution.

Lang, T. (2011). Urban resilience and new institutional theory - A happy couple for urban and regional studies. In B. Muller (Ed.), Urban and regional resilience: How do cities and regions deal with change? (pp. 15-24). Berlin: Springer-Verlag.

Mazza, L., \& Rydin, Y. (1997). Urban sustainability: Discourses, networks and policy tools. Progress in Planning, 47(1), 1-74.

Milliyet Gazetesi. (2013). Protesto AVM'ye sıçradı, Kanyon ayakta! http://www.milliyet.com.tr/protesto-avm-ye-sicradi-kanyon/ gundem/detay/1718044/default.htm (accessed 03.06.13).

Moudouros, N. (2014). Rethinking Islamic hegemony in Turkey through Gezi Park. Journal of Balkan and Near Eastern Studies, 16(2), 181-195.

Muller, B. (Ed.). (2011). Urban and regional resilience: How do cities and regions deal with change? Berlin: Springer-Verlag.

Mugan, G., \& Erkip, F. (2009). Discrimination against teenagers in the mall environment: A case from Ankara, Turkey. Adolescence, 44, 209-232. 
Nemeth, J. (2009). Defining a public: The management of privately owned public space. Urban Studies, 46(11), 2463-2490.

Neumark, D., Zhang, J., \& Ciccarella, S. (2006). The effect of walmart on local labor markets. Presentation at Wal-Mart Economic Impact Research Conference, Washington, DC, November 2005, and NBER Working Paper No. 11782.http://www.economics.uci. edu/docs/2006-07/Neumark-11.pdf (accessed 09.09.08).

Cuyahoga County Planning Commission for the Northeast Ohio Areawide Coordinating Agency (NOACA). (2000, August). Northeast Ohio Regional Retail Analysishttp://planning.co. cuyahoga.oh.us/retail/ (accessed 11.24.08).

Ozcan, G. B. (2000). The transformation of Turkish retailing: Survival strategies of small and medium-sized retailers. Journal of Southern Europe and the Balkans, 2(1), 105-120http://www.cnu.org/ node/1360 (accessed 08.23.07).

Ozuduru, B. H. (2013). Assessment of spatial dependence using spatial auto-regression models: An empirical analysis of shopping center space supply in Ohio. Journal of Urban Planning and Development, 139(1), 12-21.

Ozuduru, B. H., \& Guldmann, J. M. (2013). Retail location and urban resilience: towards a new framework for retail policy. S.A.P.I.EN.S [Online] 6(1)http://sapiens.revues.org/1620.

Ozuduru, B. H., \& Varol, C. (2009). Kent Merkezlerine Yeni Bir Alternatif: Ankara'daki Alisveris Merkezlerinin Kentsel ve Mekansal Gelisime Etkileri. An Alternative to City Centers: The Impact of Shopping Centers in Ankara on Urban and Spatial Development]. 6-8 Kasım, 33. Sehircilik Gunu Kolokyumu Kitabı, Akdeniz University, Antalya (pp. 307-324).

Ozuduru, B. H., \& Varol, C. (2011). Ankara'daki Alisveris Merkezlerinin ve Alisveris Potansiyelinin Mekansal Dagiliminin Perakende Yersecim Modelleriyle Analizi, 108 K547 nolu 3501 Uusal Genc Arastirmaci Kariyer Gelistirme Programi tarafindan desteklenen proje raporu, Tubitak, Sobag, Ankara.

Ozuduru, B. H., Varol, C., \& Ercoskun, O. Y. (2014). Do shopping centers abate the resilience of shopping streets? The co-existence of both shopping venues in Ankara, Turkey. Cities, 36(1), 145-157.

Planet Retail, 2013, press release, 4.12.2013.

Porter, L., \& Davoudi, S. (2012). The politics of resilience for planning: A cautionary note. Planning Theory and Practice, 13(2), 329-333.

Replacis. (2011). Retail planning for cities sustainability. Final report, the Urban-Net Project.

Shamsuddin, S., \& Ujang, N. (2008). Making places: The role of attachment in creating the sense of place for traditional streets in Malaysia. Habitat International, 32(3), 399-409.

Shaw, K. (2012). 'Reframing' resilience: Challenges for planning theory and practice. Planning Theory and Practice, 13(2), 308312.

Simmie, J., \& Martin, R. L. (2010). Editor's choice: The economic resilience of regions: Towards an evolutionary approach. Cambridge Journal of Regions, Economy and Society, 3(1), 27-43.

Southworth, M. (2005). Reinventing main street: From mall to townscape mall. Journal of Urban Design, 10(2), 151-170.

Staeheli, L. A., \& Mitchell, D. (2006). USA's Destiny? Regulating space and creating community in American shopping malls. Urban Studies, 43(5-6), 977-992.
Stumpp, E. M. (2013). New in town? On resilience and resilient cities. Cities, 32, 164-166.

Teller, C. (2008). Shopping streets versus shopping malls - Determinants of agglomeration format attractiveness from consumers' point of view. International Review of Retail, Distribution and Consumer Research, 18(4), 381-403.

The Ministry of Customs and Trade. (2013). Perakende Ticaretin Düzenlenmesi Hakkında Kanun TasarlsıDraft of the proposed law for regulation of retail trade]. http://www.gtb.gov.tr/banner/ perakende-ticaretin-duzenlenmesi-hakkinda-kanun-tasarisi (accessed 15.12.13).

The Ministry of Public Works and Settlement, official reports of The Council of Urbanization. 2009, May. http://www.eukn.org/ E_library/Urban_Policy/KENTGES_Integrated_Urban_ Development_Strategy_and_Action_Plan_2010_2023_Turkey (accessed 12.12.13).

Tokatli, N., \& Boyaci, Y. (2001). The changing wholesaling industry in the post-1990 Turkey: Three case studies. Journal of Euromarketing, 10, 65-92.

Tokatli, N., \& Erkip, F. (1998). Foreign investment in producer services: The Turkish experience in the post-1980 period. Third World Planning Review, 20, 87-105.

Tokatli, N., \& Boyaci-Eldener, Y. (2002). Globalization and the changing political economy of distribution channels in Turkey. Environment and Planning A, 34(2), 217-238.

Tokatli, N., \& Boyaci, Y. (1999). The changing morphology of commercial activity in Istanbul. Cities, 16(3), 181-193.

Tokatli, N., \& Boyaci, Y. (1998). The changing retail industry and retail landscapes: The case of post-1980 Turkey. Cities, 15, 345359.

Toprak, Z. (1995). Tuketim Oruntuleri ve Osmanli Magazalari [Consumption Patterns and the Ottoman Stores]. Cogito: Dunya Buyuk bir Magaza, World is a Big Store5, 25-28.

Turkish Higher Education Institution (YOK) official website, yok.gov.tr (accessed 03.01.14)

T.R. Ministry of Development/T.C. Kalkinma Bakanligi (DPT). (2003). Iller ve Bolgeler Itibariyle Gayri Safi Yurtici Hasiladaki Gelismeler (1987-2000) [The Improvement in Gross Domestic Product in Cities and Regions (1987-2000)]. Ankara: Devlet Istatistik Enstitusu Matbaasi.

Turkish Competition Authority. (2008). Rekabet El Kitabi. Ankara: Türkiye Rekabet Kurumu.

Turkish Statistical Institute. (2009). Bolgesel Gostergeler, TR51. Regional Indicators, TR51]. Ankara: TUIK Yayinlari

Varol, C., \& Ozuduru, B. (2010). Türkiye'de Perakende Sektörünün ve Alışveriş Merkezlerinin Örgütsel ve Yasal Durumları. Mimarlık Dergisi Dosya Serisi, 22, 30-40.

International Investors Association official website, yased.org.tr (accessed 09.12.13).

West, D. M., \& Orr, M. (2003). Downtown malls as engines of economic development, community spirit and political capital. Economic Development Quarterly, 12(2), 193-204.

Zaman Pazar. (2009). AVM'ler, Krizde Tesettur Markalarina Vetoyu Kaldirdihttp://www.zaman.com.tr/ pazar_avmler-krizde-tesettur-markalarina-vetoyu_kaldirdi (accessed 29.05.14).

Feyzan Erkip Assoc. Prof. Dr., received her PhD from the Department of City and Regional Planning at Middle East Technical University (METU) in Ankara, Turkey. She was a research assistant at METU and TUBITAK before joining the Department of Interior Architecture and Environmental Design of Bilkent University, where she worked between 1990 and 2013. Her publications appeared in various journals including Environment and Planning A, Cities, 
European Urban and Regional Research, Environment and Behavior, Journal of Environmental Psychology and Third World Planning Review. She is a member of the editorial boarh of Cities. She carried out research at NYU-Poly during 2011-2012 and at Tilburg University during 2003-2004 as a visiting professor. She received URBAN-NET, Middle East Research Competition and TUBITAK research awards. Her research interests include urban transformations and consumption sites, leisure practices and spaces, environmental psychology and environmental design research.

Burcu H. Ozuduru, Assoc. Prof. Dr., completed her PhD in the Department of City and Regional Planning at the Ohio State University in Columbus, Ohio. She received her bachelor and masters degrees from the Department of City and Regional Planning at Middle East Technical University (METU) in Ankara, Turkey. She began her academic career at METU as a research assistant. She worked at retail business headquarters and real estate research companies in Columbus during her $\mathrm{PhD}$, and currently, she is an associate professor in the Department of City and Regional Planning at Gazi University. She won two national grants from TUBITAK and currently she is coordinating another one. She published in various journals, such as Journal of Urban Planning and Development and Cities. Her research interests include real estate development, quantitative methods in urban planning, GIS, spatial statistics, location models and urban growth. 